\title{
Impact of short rotation willow as riparian land-use practice on soil organic carbon fractions and composition from two contiguous wetland systems in the prairie pothole region.
}

\section{Shayeb Shahariar ( $\sim$ shayeb.shahariar@usask.ca )}

University of Saskatchewan https://orcid.org/0000-0001-6559-0548

\section{Derek Peak}

University of Saskatchewan

Raju Soolanayakanahally

Agriculture and Agri-Food Canada

Angela Bedard-Haughn

University of Saskatchewan

\section{Research Article}

Keywords: land-use practice, soil organic carbon (SOC), soil organic carbon fraction and chemical composition, Fourier Transform Infrared (FTIR) spectroscopy, marginal riparian wetland soil, prairie pothole region (PPR)

Posted Date: June 17th, 2021

DOl: https://doi.org/10.21203/rs.3.rs-568432/v1

License: (c) (i) This work is licensed under a Creative Commons Attribution 4.0 International License. Read Full License

Version of Record: A version of this preprint was published at Agroforestry Systems on October 27th, 2021. See the published version at https://doi.org/10.1007/s10457-021-00694-8. 


\section{Abstract}

Evaluating the impact of land-use practices on soil organic carbon (SOC) in the Canadian prairie pothole region (PPR) is of concern due to the potential to sequester carbon and sustaining soil health. In a field experiment, SOC content, carbon fractions, and chemical composition were assessed under short rotation willow (SRW) plantation in the marginal riparian zones of two PPR wetland sites and compared with adjacent annual crop (AC) and pasture (PA). The SOC, water extractable (WEOC), light fraction (LFOC), and particulate organic carbon (POC) were used to evaluate the content and its fractions, whereas Fourier Transform Infrared (FTIR) spectroscopy was used to characterize the chemical composition. The SOC was higher in PA in both sites; however, significant $(p<0.05)$ only in site B. The SOC, LFOC, and POC followed a similar land-use pattern in both sites, i.e., PA > SRW = AC. The SOC and WEOC were significantly higher $(p<0.05)$ in $0-15 \mathrm{~cm}$ across all land-use practices. The ratios of phenolic and amides to polysaccharides were significantly higher $(p<0.05)$ in site A, while aromatic and carboxylic to polysaccharides were lower under SRW in both sites indicated microbial synthesis of these substances. The abundance of SOC functional groups was higher in the subsoil, accompanied by altered spectral properties with depths showing the potential soil organic matter transformation related to carbon fractions changes. The higher alkyl-C to 0 -alkyl-C ratio at 15-30 cm under SRW suggested a higher degree of decomposition and better SOC stability.

\section{Introduction}

Soil organic carbon (SOC) is a critical component of soil health, plays an essential role in the global carbon cycle (Janzen 2004), and supports ecosystem services (i.e., nutrient cycling and production, habitat, biodiversity etc.) through a variety of soil functions (Adhikari and Hartemink 2016). Globally, soil is the largest terrestrial pool of organic carbon (OC), which is about 2.3 times greater than atmospheric $\mathrm{CO}_{2}$ and 3.5 times higher than the $\mathrm{C}$ in all living terrestrial plants (Lal 2004), and 54\% stored in the upper one meter (Jobbágy and Jackson 2000). Terrestrial wetlands can store more than $20-30 \%$ of the total earth's SOC (Mitsch and Gosselink 2015), higher than the $0.5-2 \%$ C generally found in agricultural soils (Vepraskas and Craft 2016).

The dynamics of SOC are affected by its stability, which is a crucial mechanism of C sequestration (Paul 2016). The stability of SOC depends on its physical fractions and chemical composition (Han et al. 2016). The stability of SOC can be characterized as labile carbon (LC), slow carbon (SC), or recalcitrant carbon (RC) based on the turnover rate (Six et al. 2002b), and into light fraction (LF) or heavy fraction (HF) based on density (Golchin et al. 1994). Compared to RC, LC pools tend to react disproportionately to changes affecting the balance of SOC over a short period (Lucas and Weil 2012). Labile carbon pools of SOC, such as particulate organic carbon (POC) (53-2000 $\mu \mathrm{m})$, light fraction organic carbon (LFOC) (density $<2.0 \mathrm{~g} \mathrm{~cm}^{-3}$ ), and water extractable organic carbon (WEOC) (or dissolved organic carbon) are relatively small, have a fast turnover rate, and are easily affected by land management practices (Six et al. 2002b; Mirsky et al. 2008). Hence, LC pools can be used as preliminary indicators to assess whether a particular land-use practice will act as a C sink or source (Gregorich et al. 1994; Sainepo et al. 2018). 
The rate of SOC accumulation depends on the quantity of organic matter input and its mineralization rate (or decomposition) in soil (Kayranli et al. 2009). The rate of SOC decomposition is usually controlled by the molecular structure of organic matter added to the system, biological and environmental factors (Schmidt et al. 2011), such as litter quality and microbial community, which is closely related to $C$ dynamics (Schimel and Schaeffer 2012), and biogeochemical cycling in the agroecosystems (Ondrasek et al. 2019). The quality, function, and biochemical stability of SOC depend on the relative abundance of soil $\mathrm{LC}$ versus RC functional groups (Beer et al. 2008). As the soil organic matter (SOM) under different vegetation types from contrasting land-use practices decomposes, the chemical composition of SOC changes (Lafleur et al. 2015; Deng et al. 2019). Advanced analytical techniques such as Fourier Transform Infrared (FTIR) spectroscopy can reveal the biochemical characteristics at molecular-scale and relative abundance of $\mathrm{C}$ compounds (i.e., polysaccharides, phenolic, amides, aromatic, carboxylic) via the ratios of RC and LC fractions (Calderón et al. 2013). FTIR spectroscopy analyzes the vibrational characteristics of the structural chemical bonds that allow identifying principal chemical forms of organic compounds present in the SOM (Artz et al. 2008).

Land-use practice changes impact the quantity and chemical composition of SOC (Ramesh et al. 2019). Changes in plant species, primary productivity, litter quantity, and quality under different land-use practices can affect SOC pools directly and indirectly (Schoeneberger 2008). A meta-analysis reported an increase in SOC with a land-use change from the annual crop (AC) to pasture (PA) $(+19 \%)$ or forest (plantation forest $+18 \%$; secondary forest $+54 \%$ ) (Guo and Gifford 2002). Likewise, another metaanalysis observed a significant increase in SOC stock due to land-use conversion to agroforestry from both AC and PA (De Stefano and Jacobson 2017). However, the changes in SOC content are greatly influenced by the climatic/environmental condition at the global scale and the natural variations in edaphic conditions and management at the local level (Stockmann et al. 2013). Changes in soil C content often occur gradually and can be challenging to detect in the short term, especially if high background levels are already present (Gregorich et al. 1994).

The prairie pothole region (PPR) is a distinctive landscape in North America commonly known for its millions of small wetlands, large areas of the native prairie (Winter 1989), and highly productive agricultural lands (Gleason et al. 2011). The PPR wetlands provide various ecological benefits, including carbon sequestration (Euliss et al. 2006). Under the anoxic soil environments, slow decomposition of PPR freshwater mineral wetlands leads to SOC accumulation, and such wetlands account for $18 \%$ of the global wetland C pool (Bridgham et al. 2006). However, cultivation within the PPR has disrupted the native vegetation and led to SOC loss (Janzen et al. 1998). Natural solutions include land-use-centered management interventions, which typically allocate a significant fraction of their biomass and/or reduce the decomposition rates to enhance SOC (Paustian et al. 2016). Across the PPR, millions of hectares of marginal lands, including wetland riparian zones, are not suitable for cultivation (Amichev et al. 2014b). In Saskatchewan, Canada, more than 2 million hectares (ha) of marginal degraded lands have the potential for $\mathrm{C}$ sequestration through short rotation willow (SRW) biomass production (Amichev et al. 2012). Hence, the establishment of SRW within the PPR could promote soil biological activity and SOC compared to AC; however, in the short term, it is usually lower than the PA (Stauffer et al. 2014). 
Short rotation willow is a high-density, fast-growing, biomass-producing crop harvested under short rotation cycles for bioenergy purposes, which is of increasing interest in North America (Amichev et al. 2014b). It is also increasingly used in ecological restoration, nutrient buffering, and riparian erosion control (Kuzovkina and Quigley 2005). It explored as a bioenergy feedstock source on marginal lands (Liu et al. 2017a), including wetland riparian zones within the PPR in Saskatchewan, Canada (Amichev et al. 2014a). Shifting land-use practices to SRW from arable crops is likely to result in a net increase or neutral effect on soil C (Dimitriou et al. 2012; Qin et al. 2016); however, changing from grassland to SRW can be broadly neutral or decrease soil C (Harris et al. 2015; Harris et al. 2017). But, uncertainty remains about the SRW in grassland as the situation significantly depends on grassland type and management differences (Harris et al. 2015; Qin et al. 2016). For example, SRW can act as a net sink for $C$ and reduce greenhouse gas emissions compared to marginally managed PA (Harris et al. 2017). Hence, SRW landuse practice can sequester $\mathrm{C}$ while maintaining sustainable productivity of the soil (Oelbermann et al. 2004; Lemus and Lal 2005; Nair et al. 2010). Short rotation willow can represent a carbon sink over a long period (Pacaldo et al. 2013); however, in the short term, LC pools can be used as a tool to assess C dynamics as they can sensitively respond to changes in land-use practices (Lockwell et al. 2012). Therefore, the dilemma we need to comprehend is whether the establishment of SRW in the riparian zone of the PPR wetland system can lead to changes in SOC's quantity and characteristics and result in either a $\mathrm{C}$ sink or source during their first rotation. Our overall objective within this study was to assess the insitu effects of SRW plantation on SOC quantity and characteristics (organic carbon fractions and chemical functional groups) while considering its $\mathrm{C}$ sequestration potential compared to adjacent riparian land-use practices within the PPR wetland systems.

\section{Materials And Methods \\ 2.1. Study Site}

The field study was conducted in two neighboring PPR wetland sites (sites A and B; N 50 30.605'; W $103^{\circ}$ 43.011', elevation 579 m above sea level) in Indian Head, Saskatchewan, Canada (Fig. 1) during 20132015. The approximate extent of the area (estimated from FlySask2.ca) of site A was 1.8 ha, and site $B$ was 1.3 ha. Both field sites consist of a level to gently-rolling topography formed on loamy glacial till with non-calcareous Black Chernozemic soils of the Oxbow Association and poorly drained in depressions (Saskatchewan Soil Survey Staff 1986). The soil texture was clay loam at both sites. The 30-year climate norms (1981 to 2010) were $428.4 \mathrm{~mm}$ for annual total precipitation $(321.7 \mathrm{~mm}$ rainfall and $110.5 \mathrm{~mm}$ snowfall), and $+2.7^{\circ} \mathrm{C}$ for yearly average temperature, with minimum and maximum values of -20.1 and $+25.0^{\circ} \mathrm{C}$ respectively at the Indian Head, Saskatchewan, Environment Canada Climate Station (Environment Canada 2020)

At both sites, SRW variety Salix dasyclados Wimm. (cultivar 'India') was planted on marginal riparian zones of wetlands in June of 2013 adjacent to a 10-year-old stand of PA and an area of the AC. The estimated planting area of SRW was 0.46 ha in site A and 0.52 ha in site B (Fig. 1). The dormant hardwood cuttings of SRW were approximately $25 \mathrm{~cm}$ long and planted by inserting into the rotovated 
soil under black plastic mulch in a double-row design (13,300 plants ha- $\left.{ }^{-1}\right)$. The distance between rows was $2 \mathrm{~m}$, and the double-rows were $30 \mathrm{~cm}$ apart. No fertilizer was applied to the sites after SRW planting occurred. Earlier, at both SRW sites, only barley and oats had been grown, and the land may have been under fallow once or twice during the ten years before SRW planting. Typical crops in the study sites are barley, oats, or flax, as the land areas of both sites are slightly saline. The unmanaged PA was established ten years prior with an alfalfa (Medicago sativa) and bromegrass (Bromus madritensis) mixture and typically only subjected to light grazing in early May three to four weeks. During the study period (2013-2015), the AC was seeded to oats (Avena sativa); during the previous ten years, the AC land had been cultivated with barley, oats, and flax.

\subsection{Soil Sampling}

Soil samples $(n=28)$ were collected each fall along transects (Braidek et al. 2008) at both sites (Fig. 1) in each of the three different land-use practices in 2013, 2014, and 2015. At each sampling point, soil samples were collected from two depths $(0-15$ and $15-30 \mathrm{~cm})$ by an auger. Each transect either extended from the field boundary to the wetland edge and/or from one wetland edge to another to cover all landforms (Pennock et al. 1987) and parallel the groundwater flow direction. All soil samples were transported into the laboratory and frozen until analysis. Each sample was divided into two sub-samples. The major portion of each field-moist sample was air-dried and sieved through a 2-mm sieve (for soil physical and chemical properties, SOC, POC, LFOC, and FTIR analysis for the chemical composition of SOC). Another portion (for WEOC) was stored field-moist at $-20^{\circ} \mathrm{C}$. For soil bulk density, three replicated samples were collected at $0-15$ and $15-30 \mathrm{~cm}$ depths using a core sampler (3-cm tall $\times 5.4-\mathrm{cm}$ i.d.) from each soil sampling point.

\subsection{Physically Uncomplexed (Particulate and Light Fraction), Dissolved, and Soil Organic Carbon Analysis}

For SOC, representative sub-samples ( $\mathrm{n}=28$ from each sampling depth) were ground with a roller-mill (Arnold and Schepers 2004) and analyzed using an automated combustion technique using a Leco-2000 CNS analyzer (Leco Corporation, St. Joseph, MI, USA) (Skjemstad and Baldock 2008). Analysis of SOC involved pre-treating the soil with hydrochloric acid to remove carbonates in the ceramic crucible after weighing, then drying the sample for $24 \mathrm{~h}$ at $80^{\circ} \mathrm{C}$ before analysis for carbon. Soil bulk density was calculated from the ratio of the mass of oven-dried soil (at $105^{\circ} \mathrm{C}$ for 24 hours) to the bulk volume of core soil collected from the desired soil layer in the field (Hao et al. 2008). Equivalent mass calculations for SOC stocks were determined from the associated bulk density and thickness of soil layers and expressed into megagram per hectare ( $\mathrm{Mg} \mathrm{ha}^{-1}$ ) (Ellert and Bettany 1995). For particulate organic carbon (POC), 25 $\mathrm{g}$ of air-dried soil was separated by dispersing soil with $100 \mathrm{~mL} 5 \mathrm{~g} \mathrm{~L}^{-1}$ sodium hexametaphosphate, shaking for $16 \mathrm{~h}$, and passing the dispersed samples through a 53- $\mu \mathrm{m}$ sieve (Cambardella and Elliott 1992). Materials remaining on the sieve consisted of sand and POC, dried at $60^{\circ} \mathrm{C}$, weighed, and the obtained materials were analyzed for SOC. For light fraction organic carbon (LFOC), $25 \mathrm{~g}$ of air-dried soil was suspended in $50 \mathrm{~mL}$ of $\mathrm{Nal}$ solution (specific gravity $1.7 \mathrm{~g} \mathrm{~cm}^{-3}$ ) and dispersed for 60 min using a 
reciprocating shaker. After a settling period of $48 \mathrm{~h}$, the suspended material was transferred by suction to a filtration unit (Gregorich and Beare 2008). The composited light fraction materials were washed in 0.01 $\mathrm{M} \mathrm{CaCl}_{2}$ solution followed by distilled water, dried at $60^{\circ} \mathrm{C}$, and weighed. The LF materials were analyzed for $\mathrm{C}$ using the automated combustion technique using Leco C632 CNS analyzer (Leco Corporation, St. Joseph, MI, USA). For water extractable organic carbon (WEOC), $20 \mathrm{~g}$ of moist field soil was extracted with $30 \mathrm{~mL}$ of $5 \mathrm{mM} \mathrm{CaCl}_{2}$ solution (Chantigny et al. 2008). The resulting slurry was filtered through a vacuum filter unit equipped with a $0.45 \mu \mathrm{m}$ polycarbonate filter. The filtered solutions were analyzed for dissolved organic carbon by automated combustion procedures using a TOC-VCPN analyzer (Shimadzu Scientific Instruments, Kyoto, Japan).

\subsection{Fourier Transformed Infrared (FTIR) Spectroscopic Analysis of Soil Organic Carbon Chemical Composition}

The structural compositions of labile and recalcitrant SOC chemical functional groups were investigated by FTIR spectroscopy. Representative soil sub-samples ( $n=28$ from each sampling depth) were air-dried and finely roller-milled before analysis and measured in Attenuated Total Reflectance mode in FTIR spectrometer by pressing the powder sample on a diamond-coated ZnSe crystal. Spectral data were recorded using an FTIR spectrometer (Bruker Optics Equinox 55, Ettlingen, Germany) equipped with an $\mathrm{N}_{2(I)}$-cooled MCT detector over the range of 4000 to $400 \mathrm{~cm}^{-1}$. For all samples, ambient air was used as a background. Spectral wavenumber from 950 to $1750 \mathrm{~cm}^{-1}$ was used for SOC characterization, as all main chemical functional groups, including biochemical labile carbon (LC) and recalcitrant carbon (RC), fall within these values (Calderón et al. 2013). Absorption bands represented polysaccharides (i.e., LC fraction) at 950 to $1170 \mathrm{~cm}^{-1}$ ( $1030 \mathrm{~cm}^{-1}$ : C-O stretching and O-H deformation). Biochemically recalcitrant carbon fractions were ranged between 1400 to $1750 \mathrm{~cm}^{-1}$, specifically, phenolic and aliphatic groups ( $1420 \mathrm{~cm}^{-1}$ : C-H deformation of $\mathrm{CH}_{2}$ or $\left.\mathrm{CH}_{3}\right)$, amide groups $\left(\sim 1510 \mathrm{~cm}^{-1}\right.$ : aromatic $\mathrm{C}=\mathrm{C}$ or $\mathrm{CO}$ of amide groups), lignin and other aromatics and aromatic or aliphatic carboxylates $\left(\sim 1630 \mathrm{~cm}^{-1}\right.$ : aromatic $\mathrm{C}=\mathrm{C}$ and asymmetric $\left.\mathrm{COO}^{-}\right)$, and carboxylic acids and aromatic esters $\left(\sim 1720 \mathrm{~cm}^{-1}: \mathrm{C}=0\right.$ stretch of $\mathrm{COOH}$ or $\mathrm{COOR}$ ) (Gillespie et al. 2015). The relative abundance (ratio) of recalcitrant $\mathrm{C}$ to labile $\mathrm{C}$ (RC:LC) chemical functional groups present in soils from different land-use practices were calculated from the relative peak ratios of 1420/1030, 1510/1030, 1630/1030, and 1720/1030 .

\subsection{Statistical Analysis}

All data were statistically analyzed using the R version 3.4.4 for Windows (R Core Team 2018). The Shapiro-Wilk test and histogram were used to assess the normality of data. Levene's test was used to assess the homogeneity of variances or homoscedasticity using the "car" package. Data were square-root transformed whenever necessary to meet the assumptions of normality. Univariate analysis of variance (ANOVA) with generalized linear mixed-effects models (Bolker et al. 2009) for nested design (Krzywinski et al. 2014) through "ImerTest" was used to see a significant difference (hypothesis testing) among different land-use practices, depths and year for soil organic carbon and its fractions. When significant effects were found in ANOVA, multiple comparisons of means among land-use practices were compared 
by Tukey Honest Significant Difference test (Tukey HSD) using the "TukeyC" package. Permutation multivariate ANOVA (PERMANOVA) was used to assess significant differences (hypothesis testing) of SOC and its fractions using the "vegan" package. Non-metric multidimensional scaling (NMDS) with BrayCurtis matrix of dissimilarities was used to plot the original position in multidimensional space to visualize the difference between land-use practices and years and SOC fractions using "vegan" package. The linear relationship among soil characteristics (physical and chemical) and soil organic carbon fractions were analyzed by redundancy analysis (RDA) through the development of multiple linear regression to reflect variables in the same Cartesian coordinate system using the "vegan" package.

Spectral data obtained through FTIR were first treated for baseline correction and normalization using the "ChemoSpec" package. The FTIR spectra from each land-use practice and depth were compared quantitatively by integrating normalized data across regions assigned to soil organic carbon chemical functional groups. Significant differences in the RC:LC ratios of SOC chemical functional groups among land-use practices in different depth classes were determined through ANOVA. Multivariate analysis of the FTIR absorption band intensities was performed using PERMANOVA through the "vegan" package to see differences among land-use practices and between depths. Similarity percentage (SIMPER) was used to determine which FTIR absorption band was responsible for contrasting land-use practices and depths. Bray-Curtis distance measurement was used both for PERMANOVA and SIMPER. The heatmap representation and hierarchical cluster analysis (HCA) of both LC and RC functional groups were constructed to identify clustering in different land-use practices of depth classes using the "ChemoSpec" package. The linkage of both LC and RC with SOC and their fractions and the soil physical and chemical characteristics under different land-use practices were evaluated by constrained analysis of principal coordinates (CAP) by the "vegan" package. All statistical tests were considered statistically significant at $p$-values $\leq 0.05$.

\section{Results}

\subsection{Soil Organic Carbon Content and Fractions under Different Land-use Practices}

The SOC content was relatively greater under PA land-use practices compared to AC and SRW in both sites at both depths (Fig. 2A, B, C, J, K, L): however, differences were only significant $(p<0.05)$ in site $B$ (Table 1). The SOC was significantly $(p<0.001)$ higher at $0-15 \mathrm{~cm}$ than $15-30 \mathrm{~cm}$ depth across all landuses at both sites (Table 1). 
Table 1

Test of significance by nested ANOVA of the effects of land-use practice, soil depth, and year on labile and recalcitrant soil organic carbon fractions.

\begin{tabular}{|c|c|c|c|c|c|c|c|c|c|c|c|}
\hline & \multirow{2}{*}{$\begin{array}{l}\text { Sources of } \\
\text { variation }\end{array}$} & \multicolumn{3}{|c|}{ SOC } & \multicolumn{2}{|r|}{ WEOC } & \multicolumn{2}{|c|}{ POC } & \multicolumn{2}{|c|}{ LFOC } & \multirow[b]{2}{*}{$\begin{array}{l}\text { p- } \\
\text { value }\end{array}$} \\
\hline & & df & F stat & $\begin{array}{l}\text { p- } \\
\text { value }\end{array}$ & df & F stat & $\begin{array}{l}\mathrm{p}- \\
\text { value }\end{array}$ & $\begin{array}{l}\text { F } \\
\text { stat }\end{array}$ & $\begin{array}{l}\mathrm{p}- \\
\text { value }\end{array}$ & F stat & \\
\hline \multirow[t]{3}{*}{$\begin{array}{l}\text { Site } \\
\text { A }\end{array}$} & Land-use & 2 & 1.37 & $\begin{array}{l}0.260 \\
\mathrm{~ns}\end{array}$ & 2 & 1.55 & $\begin{array}{l}0.219 \\
\mathrm{~ns}\end{array}$ & 8.84 & $\begin{array}{l}< \\
0.001 \\
\star \star \star\end{array}$ & 13.95 & $\begin{array}{l}< \\
0.001 \\
* * *\end{array}$ \\
\hline & Depth & 1 & 39.53 & $\begin{array}{l}< \\
0.001 \\
* * *\end{array}$ & 1 & 12.54 & $\begin{array}{l}< \\
0.001\end{array}$ & - & - & - & - \\
\hline & Year & 2 & 0.25 & $\begin{array}{l}0.779 \\
\mathrm{~ns}\end{array}$ & 1 & 0.02 & $\begin{array}{l}0.895 \\
\mathrm{~ns}\end{array}$ & 1.90 & $\begin{array}{l}0.178 \\
\mathrm{~ns}\end{array}$ & 0.46 & $\begin{array}{l}0.501 \\
\mathrm{~ns}\end{array}$ \\
\hline \multirow[t]{3}{*}{$\begin{array}{l}\text { Site } \\
\text { B }\end{array}$} & Land-use & 2 & 6.52 & $\underset{\star \star}{0.002}$ & 2 & 1.49 & $\begin{array}{l}0.233 \\
\mathrm{~ns}\end{array}$ & 9.19 & $\begin{array}{l}< \\
0.001\end{array}$ & 6.95 & $\underset{\star \star}{0.004}$ \\
\hline & Depth & 1 & 31.55 & $\begin{array}{l}< \\
0.001 \\
* \star \star\end{array}$ & 1 & 10.10 & ${ }_{\star \star}^{0.002}$ & - & - & - & - \\
\hline & Year & 2 & 1.79 & $\begin{array}{l}0.173 \\
\mathrm{~ns}\end{array}$ & 1 & 6.60 & $\underset{*}{0.013}$ & 0.14 & $\begin{array}{l}0.712 \\
\mathrm{~ns}\end{array}$ & 1.01 & $\begin{array}{l}0.325 \\
\text { ns }\end{array}$ \\
\hline \multicolumn{12}{|c|}{$\begin{array}{l}\text { a } *, * *, * * * \text { Indicate there is a statistically significant difference at } p \leq 0.05, p \leq 0.01 \text { and } p \leq 0.001 \text {, } \\
\text { respectively; }{ }^{n s} \text {, is not significantly different }(p>0.05) \text {. }\end{array}$} \\
\hline
\end{tabular}

Water extractable organic carbon content was significantly different $(p<0.01)$ between depths and was significantly higher $(p<0.05)$ at the top 0-15 than 15-30 cm depth (Fig. 2; Table 1). A significant difference $(p<0.05)$ was observed in WEOC content only in site B, where 2014 had a relatively higher content than 2015. Both POC content and LFOC (measured in $0-15 \mathrm{~cm}$ only) were significantly different $(p<0.01)$ among land-use practices (Table 1$)$. The PA had significantly higher $(p<0.05)$ POC and LFOC content than AC and SRW.

Multivariate analysis of variance (PERMANOVA) was used to test the combined effects of land-use practices, depths, and time (i.e., years) on the SOC and carbon fractions (Table 2). A significant impact of depth $(p<0.001)$ was observed in site $A$, whereas, in site B the difference among land-use practices, depths, and years was statistically significant $(p<0.05)$. However, in site $B$, the variance explained as indicated by the $R^{2}$ value from the PERMANOVA test $\left(R^{2}\right.$ for land-use is 0.084 , and for the year is 0.032 ) was relatively low (Table 2 ). Similarity percent (SIMPER) results (not shown here) showed that the 
contrast between the years 2014 and 2015 was significant $(p<0.05)$ for POC and LFOC in site A, whereas for POC and WEOC in site B. Significantly higher $(p<0.05)$ contrast was observed between depths for SOC and WEOC content.

Table 2

Test of significance by nested PERMANOVA of the effects of land-use practice, soil depth, and year of labile and recalcitrant soil organic carbon fractions, and chemical functional groups from FTIR spectra.

\begin{tabular}{|c|c|c|c|c|c|c|c|c|c|}
\hline & \multirow[b]{2}{*}{$\begin{array}{l}\text { Sources of } \\
\text { variation }\end{array}$} & \multicolumn{4}{|c|}{$\begin{array}{l}\text { Labile and recalcitrant SOC } \\
\text { fractions }\end{array}$} & \multicolumn{4}{|c|}{$\begin{array}{l}\text { Labile and recalcitrant SOC chemical } \\
\text { functional groups revealed by FTIR spectra }\end{array}$} \\
\hline & & df & $\begin{array}{l}\text { F- } \\
\text { Model }\end{array}$ & $\mathrm{R}^{2}$ & $\begin{array}{l}\operatorname{Pr}(> \\
F)\end{array}$ & df & F-Model & $\mathrm{R}^{2}$ & $\operatorname{Pr}(>F)$ \\
\hline \multirow[t]{4}{*}{$\begin{array}{l}\text { Site } \\
\text { A }\end{array}$} & Land-use & 2 & 1.331 & 0.022 & $\begin{array}{l}0.247 \\
\mathrm{~ns}\end{array}$ & 2 & 2.509 & 0.141 & $0.070^{\mathrm{ns}}$ \\
\hline & Depth & 1 & 35.848 & 0.291 & $\underset{* \star \star}{0.001}$ & 1 & 4.579 & 0.129 & 0.019 * \\
\hline & Year & 2 & 0.309 & 0.005 & $\begin{array}{l}0.760 \\
\mathrm{~ns}\end{array}$ & - & - & - & - \\
\hline & Residuals & 84 & - & 0.682 & - & 26 & - & 0.730 & - \\
\hline \multirow[t]{4}{*}{$\begin{array}{l}\text { Site } \\
B\end{array}$} & Land-use & 2 & 4.635 & 0.084 & $\underset{* \star}{0.006}$ & 2 & 1.048 & 0.078 & $0.403^{\mathrm{ns}}$ \\
\hline & Depth & 1 & 24.003 & 0.216 & $\underset{\star \star \star *}{0.001}$ & 1 & 2.818 & 0.105 & 0.040 * \\
\hline & Year & 2 & 2.840 & 0.051 & $\underset{*}{0.032}$ & - & - & - & - \\
\hline & Residuals & 72 & - & 0.649 & - & 72 & - & 0.817 & - \\
\hline \multicolumn{10}{|c|}{$\begin{array}{l}\text { a } *, * *, * * * \text { Indicate there is a statistically significant difference at } p \leq 0.05, p \leq 0.01 \text { and } p \leq 0.001 \text {, } \\
\text { respectively; }{ }^{n s} \text {, is not significantly different }(p>0.05) .\end{array}$} \\
\hline
\end{tabular}

Non-metric multidimensional scaling (NMDS) of soil organic and labile carbon fractions did not differ among land-use practices in both sites (Fig. 3A, B), suggesting that land-use was not a key factor driving the variability. The NMDS ordination tends to show a clustering along with PA land-use practice in both sites, with stress values less than 0.10 , which provides a good representation of data in reduced dimension. From the NMDS plot, the association of soil LFOC with PA land-use practices is evident in both sites (Fig. 3A, B). Also, a relatively wide dispersion was noted for SRW and AC along axis 1 in both sites. The NMDS axis 1 was positively correlated with SOC and WEOC, whereas it was negatively correlated with POC and LFOC in both sites. The NMDS axis 2 was positive with POC and negatively with SOC, LFOC, WEOC in site A, and positively with SOC and POC, and negatively with LFOC and WEOC in site B (Fig. 3A, B). 
Redundancy analysis of the soil organic and labile carbon fractions were performed to explore the relationship with the measured soil physiochemical characteristics (Fig. 3C, D). The first two-component explained $98.15 \%$ and $1.84 \%$ of site A (Fig. 3C), and $70.19 \%$ and $29.81 \%$ of site B, respectively (Fig. 3D). In site $\mathrm{A}$, the vector line of bulk density, VSWC, $\mathrm{C} / \mathrm{N}$ ratio, $\mathrm{pH}, \mathrm{TSC}, \mathrm{TN}, \mathrm{NH}_{4}-\mathrm{N}, \mathrm{NO}_{3}-\mathrm{N}$, and TDN; while in site $\mathrm{B}$, the vector line of VSWC, EC, $\mathrm{C} / \mathrm{N}$ ratio, TSC, TN, $\mathrm{NH}_{4}-\mathrm{N}, \mathrm{TDN}$ were statistically significant $(p<0.05)$.

\subsection{Soil Organic Carbon Chemical Composition under Different Land-use Practices}

The normalized and averaged FTIR spectra from different land-use practices of both sites were used to distinguish the SOC chemical functional groups (Fig. 4A, B). Overall, the highest intensity absorbance peak was observed at $1030 \mathrm{~cm}^{-1}$ (absorbance range 950 to $1170 \mathrm{~cm}^{-1}$ ) due to $\mathrm{C}-\mathrm{O}$ stretching and $\mathrm{O}-\mathrm{H}$ deformation, attributed primarily to polysaccharides. Across the RC range (1400 to $\left.1750 \mathrm{~cm}^{-1}\right)$, higher absorbance peaks were observed for phenolic and amide groups (1420 and $1510 \mathrm{~cm}^{-1}$ ) both under SRW and AC in site A and under SRW and PA in site B (Fig. 4A, B). There was a smaller absorbance peak noted for aromatic and carboxylic groups (1630 and $1720 \mathrm{~cm}^{-1}$ ).

The CAP analysis based on the relative abundance of chemical functional groups by land-use practices accounted for $88.97 \%$ (74.42\% for CAP 1 and $14.55 \%$ for CAP 2$)$ in site A and $88.94 \%$ (64.92\% for CAP 1 and $23.95 \%$ for CAP 2) of the total variance in site $B$ (Fig. $4 C$ and $D$, respectively). Axis 1 from CAP analysis for both sites covered a significant variation ( $p=0.002$ in site A and $p=0.001$ in site $\mathrm{B}$ ); the ordination plots tend to separate the PA from other land-use practices with CAP 1. The chemical functional groups of SOC were separated distinctly in quadrants in both sites (Fig. 4C, D). In site A, aromatic and carboxylic were in the first quadrant, amides and phenolic in the third, and polysaccharides groups were in the fourth. In site B, amides and phenolic were in the first quadrant, polysaccharides in the second, and aromatic and carboxylic groups were in the fourth.

The mean \pm SD (standard deviations) RC:LC ratios of different chemical functional groups and significance levels from ANOVA with the Tukey HSD test are presented in Table 3. Statistically significant $(p<0.05)$ variations were observed in phenolic to polysaccharides $(1420 / 1030)$ and amides to polysaccharides (1510/1030) ratios among the land-use practices in both sites (Table 3 ). Tukey results showed that the mean ratios of phenolic to polysaccharides (1420/1030) and amides to polysaccharides $(1510 / 1030)$ for SRW were significantly $(p<0.05)$ higher than PA and AC in site A; but, AC and PA landuse practices were not significantly $(p>0.05)$ different from each other. However, in site $B$, the mean ratios of phenolic to polysaccharides (1420/1030) and amides to polysaccharides (1510/1030) for AC were significantly $(p<0.05)$ lower compared to PA and SRW; but, there was no significant $(p>0.05)$ difference observed between PA and SRW land-use practices (Table 3). 
Table 3

Mean $( \pm S D)$ ratios and significance levels from nested ANOVA of the ratios of soil RC:LC chemical functional groups from FTIR spectra under different land-use practices and soil depths.

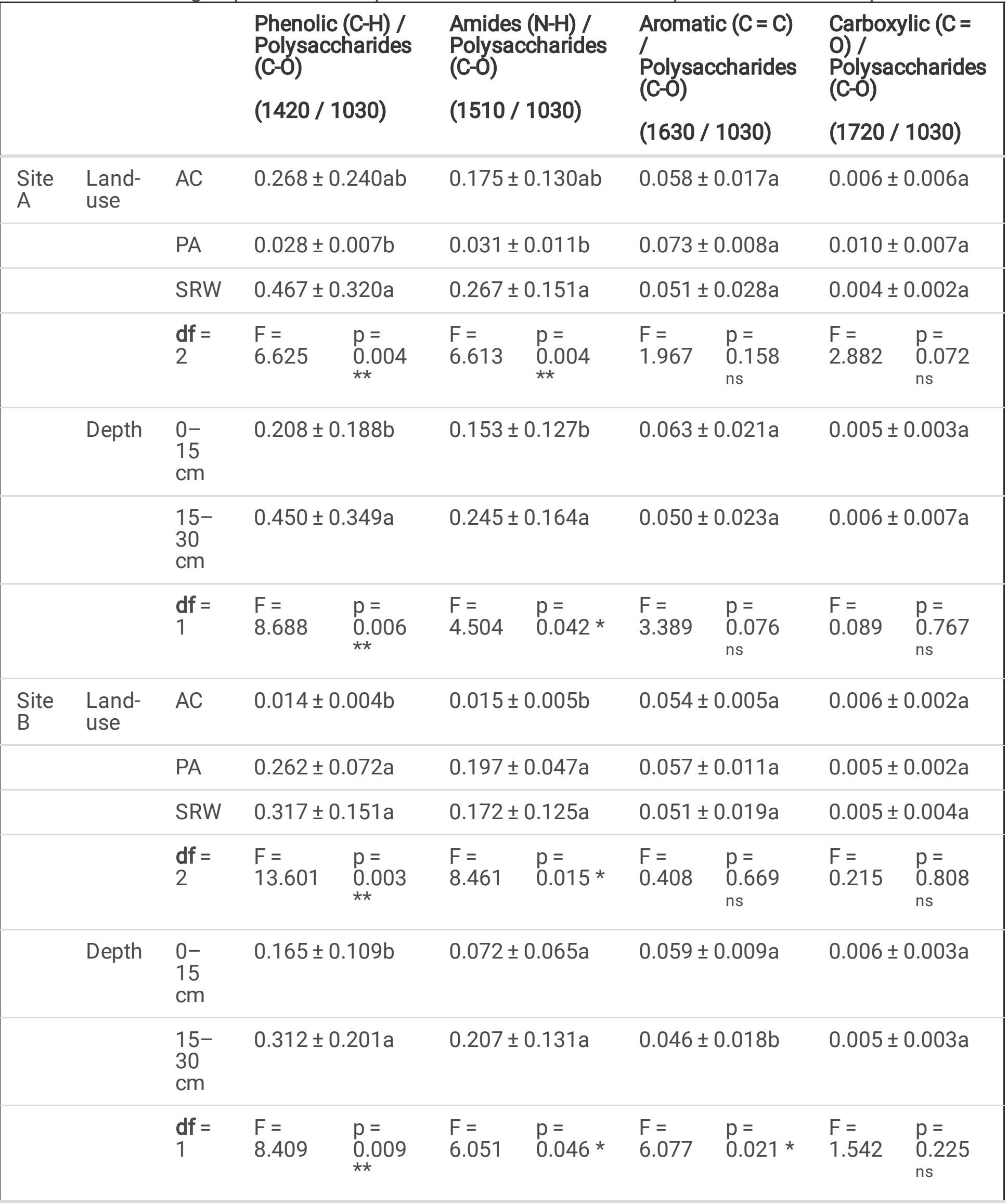




\section{Phenolic (C-H) / \\ Polysaccharides \\ (C-O)}

(1420/ 1030)
Amides (N-H) /

Polysaccharides

(C-0)

$(1510 / 1030)$
Aromatic $(C=C)$

Polysaccharides

(C-O)

(1630 / 1030)
Carboxylic $(\mathrm{C}=$

0) /

Polysaccharides

(C-0)

(1720 / 1030)

a Values represent mean \pm standard deviations $( \pm S D)$.

${ }^{b}$ Means within a column for land-use and depth followed by the same letter are not significantly different $(p>0.05)$ using Tukey HSD.

$c *, \star *, * \star \star$ Indicate there is a statistically significant difference at $p \leq 0.05, p \leq 0.01$ and $p \leq 0.001$, respectively; ${ }^{\text {ns }}$, is not significantly different $(p>0.05)$.

d $\mathrm{LC}=$ labile carbon, $\mathrm{RC}=$ recalcitrant carbon, $\mathrm{AC}=$ annual crop, $\mathrm{PA}=$ pasture, $\mathrm{SRW}=$ short rotation willow.

Overall, all the RC:LC ratios were higher at lower 15-30 compared to top 0-15 cm depth, except the ratios of aromatic to polysaccharides (1630/1030), which was opposite in both sites (Table 3 ). The mean ratio of 1420/1030 (phenolic to polysaccharides) and 1510/1030 (amides to polysaccharides) were significantly higher $(p<0.05)$ at $15-30 \mathrm{~cm}$ than at $0-15 \mathrm{~cm}$ in both sites. In site $\mathrm{B}$, the ratio of $1630 / 1030$ (aromatic to polysaccharides) at the top $0-15 \mathrm{~cm}$ was significantly $(p<0.05)$ higher compared to $15-30$ cm depth (Table 3).

The PERMANOVA indicated that FTIR band absorbances differed significantly $(p<0.05)$ between depth classes in both sites (Table 2). The SIMPER results (not shown here) showed that there were significantly higher phenolic $(p=0.03)$ and amide $(p=0.01)$ groups present in PA than SRW land-use practice, and significantly higher phenolic $(p=0.01)$ and amide $(p=0.01)$ groups at $0-15$ than $15-30 \mathrm{~cm}$ in site $\mathrm{A}$.

The heatmap with hierarchical cluster analysis revealed that, based on the land-use practices, SOC chemical functional groups could be separated into two clustering groups at both depths in both sites (Fig. 5). The AC and SRW formed an identical clustering group distinct from PA at both $0-15$ and 15-30 $\mathrm{cm}$ depth in site $A$, and $0-15 \mathrm{~cm}$ depth in site $B$ (Fig. 5A, B, C). However, at $15-30 \mathrm{~cm}$ depth in site B, PA and SRW formed an identical clustering group apart from AC land-use practice (Fig. 5D).

\section{Discussion}

\subsection{Land-use Effects on Soil Organic Carbon Content and Fractions}

Soil organic carbon content was higher in PA than other land-use practices from both sites in our experiment, which was consistent with the meta-analysis conducted by Guo and Gifford (2002). In our study, the variations are most probably attributable to differences in the nature of belowground biomass 
added from PA's delicate and dead roots for a more extended period (i.e., > 10 years). Guo et al. (2007) observed $36 \%$ higher annual inputs from the fine roots (diameter $<2 \mathrm{~mm}$ ) biomass under the PA land-use practice, but under adjacent plantation forests, fewer fine roots were produced, and roots died more slowly. The findings of Harris et al. (2017) were also consistent with our results where $0-30 \mathrm{~cm} \mathrm{SOC}$ stocks were substantially higher under PA than SRW.

The conversion of agricultural land to SRW or perennial PA caused an increase, but the conversion of grassland to SRW did not change SOC content (Harris et al. 2015). Compared to SRW, the higher $C$ content under PA land-use practice in this study can be explained by their biomass allocation; however, entire SRW plantation systems might not add a higher amount of organic $C$ inputs (Laganière et al. 2010) during their first rotation cycle. Similarly, Stauffer et al. (2014) observed lower SOC under SRW plantation compared to PA. However, due to land-use conversion from grassland to willow plantation, Qin et al. (2016) did not found any significant SOC changes.

Cultivation is the most crucial factor driving SOC loss from the agricultural soil (Lal 2006). Increased microbial decomposition of SOC is likely due to the turning and breakup of soil aggregates by tillage under AC land-use practice (Six et al. 2002a). The lower SOC content under AC land-use practice in our experiment is most likely due to removing a large portion of $\mathrm{C}$ sequestered by the grain harvest, straw removal, and repeated mechanical disturbance (i.e., tillage practices) during the crop production every year (Grigal and Berguson 1998). Similarly, Puget and Lal (2005) observed higher SOC content at 0-10 $\mathrm{cm}$ under PA land-use than cultivated soils under AC production; however, no difference was seen below $50 \mathrm{~cm}$.

A study with the first harvest of SRW (Salix species) across a wide range of soils and land-use in Canada found an initial loss of soil carbon at plantation establishment regardless of initial SOC contents (Ens et al. 2013). But, high-biomass SRW is likely to add a substantial amount of above and below ground $C$ to the soil in the subsequent years (Oelbermann et al. 2004; Nair et al. 2010). Within 2-3 years after SRW planting, the one-time effect of cultivation disturbance is diminished, decomposition will slow down, and the leaf litter input will contribute to further accumulation of SOC (Grigal and Berguson 1998). After SRW establishment, SOC contents have significantly decreased during the first five years at the upper 0-15 cm depth, followed by recovery from this point on to age 19 years (Pacaldo et al. 2013). We did not find any significant decrease or increase in SOC under SRW during the first rotation. However, a meta-analysis indicated that SOC under SRW establishment might not fully recover within the 20-30 years (Guo and Gifford 2002; Laganière et al. 2010). Ultimately, the $C$ recovery process will vary based on the management practices in the subsequent rotation under SRW, as it may receive more frequent disturbance than other land-use practices. (Six et al. 2002a) suggested that SOC within the macroaggregates of afforested soils was stabilized for a relatively long period. In our experiment, the differences in SOC among the PA, SRW, and AC land-use practices are mainly due to differences in residue inputs, which affect the $\mathrm{C}$ availability for decomposition. 
The LC fraction often comprises a substantial portion of the SOC and responds to change in input (Gregorich et al. 2006). Light fraction and particulate OC mainly originate from fresh plant residues and are significant to SOC turnover in agricultural soils because they provide a readily decomposable substrate to microorganisms (Gregorich et al. 1994). In our study, the POC and LFOC content were significantly higher under PA in the upper $15 \mathrm{~cm}$ soil than SRW and AC. The higher POC and LFOC in soils from PA are likely due to higher annual grass biomass and root litter input (Guo et al. 2007). Similar to our study, Akinsete and Nortcliff (2014) observed higher LC content under PA than AC. However, other researchers have found that labile forms of $C$ were lower in PA soils (Paul et al. 2008) and agricultural soils (Purakayastha et al. 2007) compared to secondary or plantation forests and that POC was not different (Sainepo et al. 2018) between AC and PA land-use practices.

Water extractable organic carbon was higher under SRW, followed by AC and PA in both sites of our experiment. The WEOC was correlated with SOC and found to be relatively lower under agriculture than forest soils, which indicated a significant effect of land-use practices (Ćirić et al. 2016). The content of WEOC in the AC soils can be 4-5 times lower than PA because of continuous cultivation (Ghani et al. 2003). In this experiment, a decreased WEOC content was observed in the subsoil (i.e., 15-30 cm), indicating the reduction of labile $\mathrm{C}$ pools under SRW after two years of establishment (Lockwell et al. 2012). Hence, it has been proposed that the WEOC content can significantly decrease with increasing soil depth (Zhang et al. 2006).

Plant biomass production and allocation from different land-uses are major factors that strongly affect SOC distribution patterns with depth (Jobbágy and Jackson 2000). Plant litter amount, composition, and availability also control the quantity and the chemical properties of SOC; yet, soil physiochemical conditions could boost or impede the decomposition of organic matter (Gregorich et al. 2006). In our experiment, SOC and WEOC contents were significantly higher at $0-15 \mathrm{~cm}$ than $15-30 \mathrm{~cm}$ depth among contrasting land-use practices, suggesting that perhaps the effects of land-uses remained confined to the soils' surface layer (Young et al. 2005; Zhang et al. 2006). Our results also implied that the $C$ content does not remain constant with depths (Young et al. 2005). A meta-analysis revealed that the conversion of agricultural land to agroforestry significantly increased the SOC 26,40 , and $34 \%$ at $0-15,0-30$, and 0 $100 \mathrm{~cm}$ depths, respectively (De Stefano and Jacobson 2017). Likewise, the study with long-term (10-20 years) SRW cultivation observed significantly higher SOC content in topsoil ( $9 \%)$ and subsoil (27\%) than adjacent AC (Dimitriou et al. 2012). However, the dynamics of SOC and their fractions between topsoil $(0-20 \mathrm{~cm})$ and subsoil $(20-100 \mathrm{~cm})$ were unchanged (Liu et al. 2017b).

\subsection{Land-use Effects on Soil Organic Carbon Chemical Composition}

Research has suggested that altered leaf litter quality due to the difference in vegetation can control the chemical composition and structure of SOC (Guo et al. 2016). The RC:LC ratio can better explain the degree of decomposition and the stability of SOC via its enrichment in phenolic, aromatic, and carboxylic groups relative to polysaccharides (Deng et al. 2019). Contrasting land-use practices significantly 
affected the RC:LC ratio of phenolic to polysaccharide (alkyl-C/O-alkyl-C) and amide to polysaccharide (amide/O-alkyl-C) in both sites in our study. A higher value of the RC:LC ratio represents a higher degree of decomposition and better stability of SOC (Baldock et al. 1997). In this experiment, the relative abundance of alkyl-C (i.e., phenolic) and amide groups were higher, and O-alkyl-C (i.e., polysaccharides) was lower, whereas the ratios of phenolic and amides to polysaccharides were higher under SRW compared to AC and PA land-use practice. Lafleur et al. (2015) found substantially higher alkyl-C and Oalkyl-C in soil under SRW after two to six years compared to an adjacent agricultural field. Like our experiment, the authors observed a considerably higher alkyl-C to O-alkyl-C ratio under SRW than in the agricultural field. The presence of a higher alkyl-C chemical functional group under SRW indicates compounds resistant to decomposition, such as fatty acids, waxes, and resins, compared to other landuse practices. It has been indicated that the leaf litters or roots or both under SRW are more resistant to decay compared to litter produced by agricultural land-use practices (Lafleur et al. 2015). Hence, Lafleur et al. (2015) indicated that the leaf litter decomposition of SRW initially occurred quickly than that of the reference field in the topsoil; however, with the progress of decay the SOC become more decay resistant.

On the other hand, the O-alkyl-C, amides, and aromatic groups such as carbohydrates, amino acids, amino sugars, and lignin are less resistant to decay than the alkyl-C (Golchin et al. 1994; Baldock et al. 1997). In our study, the relative abundance of polysaccharides was higher, while the alkyl-C and amides were lower under AC; however, aromatic and carboxylic functional groups were higher in both sites. Helfrich et al. (2006) observed a decrease in O-alkyl-C with an increase in alkyl-C abundance via the decomposition of forest litters, whereas the O-alkyl-C was highest, and alkyl-C, aryl-C, and carbonyl-C contents were lowest under the forest and grassland compared to agricultural soil. Hence, it indicated that both grassland and agricultural soils contained a higher proportion of aryl-C and carbonyl-C and were dominated by the mineral-associated SOC. While the increased relative abundance of aromatic-C groups under agricultural soils induced by the cultivation with the decrease of SOC content (Helfrich et al. 2006). Solomon et al. (2005) further supported that the aromatic $C$ groups dominate soils under plantations and continuously cultivated soils.

The prairie's grassland soil has been shown to have higher absorbance at $\mathrm{C}-\mathrm{H}$ (phenolic and aliphatic groups) at $0-15 \mathrm{~cm}$, indicating higher SOC content and different spectral properties to the adjacent cropland under wheat (Calderón et al. 2011). The O-alkyl-C (i.e., polysaccharides) is more substantial in long-term PA than a cultivated agricultural soil and primarily present as a POC fraction occluded within the stable soil aggregate (Golchin et al. 1995). In our experiment, the PA land-use has not been cultivated for at least ten years, SRW was cultivated once three years before establishment, and AC has been cultivated every year. Also, we observed significantly higher POC and LFOC contents under PA land-use practice than SRW and AC. Perhaps, in an uncultivated soil like PA, an stable soil C pool developed within the soil aggregates during the decades of root growth, and the relatively higher O-alkyl-C abundance is associated with SOC in the occluded LF, which is usually lost by cultivation (Golchin et al. 1994).

The FTIR analysis of soil revealed that depth has more influence on SOC functional groups than land-use practice. The relative abundance of FTIR bands of all SOC chemical functional groups and the RC:LC 
ratios of phenolic, amide, and carboxylic to polysaccharides were lower, whereas aromatic to polysaccharide ratio was higher at $0-15 \mathrm{~cm}$ depth in both sites. Dhillon et al. (2017) observed decreased polysaccharides and carboxylic groups with depth, whereas the aromatics increased with depth under both shelterbelt agroforestry and adjacent agricultural land-use practices in Saskatchewan, Canada. The research suggested that a higher phenolic compound results in higher $\mathrm{C}$ retained levels in the soil (De Nobili et al. 2009). From litter bag experiment showed that willow leaf has high levels of phenolics (i.e., tannins), decomposes at slower rates, and forms recalcitrant complexes such as cellulose or proteins (Schofield et al. 1998). Slower SOM decomposition may perhaps cause by the slower microbial activity under high phenol-containing litters under SRW (Rahman and Rahman 2012). Therefore, in our experiment, the higher abundance of phenolic functional groups in the subsoil (i.e., 15-30 cm) perhaps indicates increased SOC stability and rapid leaching loss of lower molecular weight tannins (Schofield et al. 1998) from the surface soil under SRW land-use practice. Schofield et al. (1998) found that phenolics from willow leaf litter may decrease quickly (i.e., within six weeks) in topsoil and decrease SOC content under temperate climate conditions. However, Lafleur et al. (2015) found that net accumulation of SOC can occur in the topsoil from litterfall within two to three years of afforestation under a cold climatic environment in southern Quebec. Under cold climatic conditions such as in our experimental sites, the time to reach a new equilibrium of SOC following SRW plantation might be quite long due to the slower decomposition rates of SOM (Hättenschwiler and Vitousek 2000). Our results support that SOC chemical composition shifts with depth and labile $\mathrm{C}$ molecules are more common in the subsoil (Vancampenhout et al. 2012). The relative intensities of FTIR absorbance bands and the RC:LC ratios were consistent and followed a similar pattern with depths, indicating similar variation in SOC composition under different soil depths across contrasting land-use practices in this study.

The RC:LC ratio of phenolic to polysaccharides was significantly higher in site $\mathrm{A}$ only, and aromatic to polysaccharide was significantly lower at $15-30 \mathrm{~cm}$ compared to $0-15 \mathrm{~cm}$ depth in our field experiment. The increased amount of alkyl-C, aromatic- $\mathrm{C}$, and carbonyl-C accumulation at depth may reflect reduced decomposition or microbial synthesis of these materials in soil (Gregorich et al. 1996). Compared to topsoil OC, a higher amount of microbial-derived C compounds and the decreased proportions of energyrich plant-derived materials in the subsoil is very common (Rumpel and Kögel-Knabner 2010). Hence, the aromatic group (i.e., lignin) decreased, whereas aliphatic compounds increased with depth in soil (Feng and Simpson 2007). More substantial absorbance of polysaccharides (e.g., carbohydrates), carboxylic, and ester bands at the surface $(0-5 \mathrm{~cm})$ compared to higher $(5-15 \mathrm{~cm})$ soil depth in the prairie indicates different spectral properties with soil depth (Calderón et al. 2011).

\section{Conclusions}

Land-use practices can affect SOC content, fractions, and chemical composition substantially. Overall, the LFOC, POC, and SOC followed a similar land-use pattern in both sites in the order of PA > SRW = AC. The PA had significantly higher SOC, whereas comparatively higher WEOC content was observed under SRW land-use practice. The upper $15 \mathrm{~cm}$ soil comprised higher SOC, indicated that the depth influenced C storage across all land-use practices.

Page $16 / 33$ 
Soil FTIR analysis revealed that depth has more influence on SOC functional groups than does land-use practice. A relatively lower abundance of FTIR bands of all SOC chemical functional groups were observed in the $0-15 \mathrm{~cm}$ layer. Likewise, the RC:LC ratios of phenolic, amide, and carboxylic to polysaccharides were relatively lower in $0-15 \mathrm{~cm}$, while aromatic to polysaccharides was higher in both sites. The relative abundance of FTIR absorbance bands and the RC:LC ratios were consistent and followed a similar pattern with depths across the land-use practices. The relatively higher abundance of SOC functional groups in the subsoil indicated altered spectral properties with depths. A higher value of the alkyl-C to O-alkyl-C ratio suggested a higher degree of decomposition and better SOC stability in the subsoil.

Evidently, in a short-term period (e.g., during their first rotation), our study indicates that establishing SRW plantation in degraded marginal riparian wetland soils of the PPR has a limited impact on SOC content compared to AC. Simultaneously, the absence of cultivation under SRW plantation could slow down decomposition, and leaf litter addition will further help maintain SOC. The higher relative abundance of alkyl-C (i.e., phenolic) groups under SRW suggested better stability of organic carbon in the soil; therefore, in the successive rotations, fast-growing and high biomass producing SRW could be a substantial C sink. Eventually, planting SRW can be a realistic land-use practice for potential $C$ sequestration and environmental benefits in the PPR.

\section{Declarations}

\section{Funding}

This work was financially supported by a Natural Sciences and Engineering Research Council of Canada (NSERC) Discovery Grant to ABH (RGPIN-2017-05909) and Agriculture and Agri-Food Canada (AAFC) ABase (LOI 1231) funding support to RS. Also, SS received funding support from AAFC's Research Affiliate Program. The funding agency had no role in study design, data collection and analysis, the decision to publish, or preparation of the manuscript.

\section{Grant disclosures}

The authors disclosed the following grant information: N/A

Natural Sciences and Engineering Research Council of Canada (NSERC): N/A

Agriculture and Agri-Food Canada (AAFC): N/A

\section{Conflicts of interest/Competing interests}

The authors declare no conflict of interest/competing interests.

\section{Availability of data and material (data transparency)}

All relevant data and materials from this experiment are included in the manuscript. 
Code availability (software application or custom code)

Not applicable

\section{Authors' Contributions}

- Shayeb Shahariar: Conceptualization, Methodology, Investigation, Formal analysis, Visualization, Writing - Original Draft, Writing - Review \& Editing.

- Derek Peak: Resources, Writing - Review \& Editing.

- Raju Soolanayakanahally: Funding acquisition, Resources, Writing - Review \& Editing

- Angela Bedard-Haughn: Funding acquisition, Resources, Supervision, Writing - Review \& Editing.

\section{Ethics approval}

This article does not contain any studies with human or animal subjects performed by any of the authors.

\section{Consent to participate}

Not applicable

\section{Consent for publication}

Not applicable

\section{Acknowledgments}

The authors want to thank Ron Gares, Brian Bogdan, and Derek Durun from the Agroforestry

Development Centre, Agriculture and Agri-Food Canada, Indian Head for their help during the experimental field setup and soil samples collection. We also thank Amanda Schurman, Cassidy Oborowsky, and Cierra Wallington, summer research assistants from Applied Pedology Lab, for their soil sample collection and preparation efforts. A special thanks to Dr. Gurbir Singh Dhillon for his assistance with operating FTIR from the Environmental Soil Chemistry Lab, Department of Soil Science, University of Saskatchewan, Canada.

\section{References}

- Adhikari K, Hartemink AE (2016) Linking soils to ecosystem services - A global review. Geoderma 262:101-111. https://doi.org/10.1016/j.geoderma.2015.08.009

- Akinsete SJ, Nortcliff S (2014) Storage of Total and Labile Soil Carbon Fractions Under Different LandUse Types: A Laboratory Incubation Study. In: Hartemink AE, McSweeney K (eds) Soil Carbon. Springer International Publishing, Cham, pp 197-207. https://doi.org/10.1007/978-3-319-04084-4_21

- Amichev BY, Hangs RD, Bélanger N, Volk TA, Vujanovic V, Schoenau JJ, Van Rees KCJ (2014a) FirstRotation Yields of 30 Short-Rotation Willow Cultivars in Central Saskatchewan, Canada. BioEnergy 
Research:1-15. http://doi.org/10.1007/s12155-014-9519-4

- Amichev BY, Hangs RD, Konecsni SM, Stadnyk CN, Volk TA, Bélanger N, Vujanovic V, Schoenau JJ, Moukoumi J, Van Rees KCJ (2014b) Willow Short-Rotation Production Systems in Canada and Northern United States: A Review. Soil Sci Soc Am J 78:S168-S182.

http://doi.org/10.2136/sssaj2013.08.0368nafsc

- Amichev BY, Kurz WA, Smyth C, Van Rees KCJ (2012) The carbon implications of large-scale afforestation of agriculturally marginal land with short-rotation willow in Saskatchewan. GCB Bioenergy 4:70-87. http://doi.org/10.1111/j.1757-1707.2011.01110.x

- Arnold S, Schepers J (2004) A simple roller-mill grinding procedure for plant and soil samples. Commun Soil Sci Plant Anal 35:537-545

- Artz RRE, Chapman SJ, Jean Robertson AH, Potts JM, Laggoun-Défarge F, Gogo S, Comont L, Disnar JR, Francez A-J (2008) FTIR spectroscopy can be used as a screening tool for organic matter quality in regenerating cutover peatlands. Soil Biol Biochem 40:515-527.

http://dx.doi.org/10.1016/j.soilbio.2007.09.019

- Baldock JA, Oades JM, Nelson PN, Skene TM, Golchin A, Clarke P (1997) Assessing the extent of decomposition of natural organic materials using solid-state 13C NMR spectroscopy. Aust J Soil Res 35:1061-1083. http://doi.org/10.1071/S97004

- Beer J, Lee K, Whiticar M, Blodau C (2008) Geochemical controls on anaerobic organic matter decomposition in a northern peatland. Limnol Oceanogr 53:1393-1407. https://doi.org/10.4319/lo.2008.53.4.1393

- Bolker BM, Brooks ME, Clark CJ, Geange SW, Poulsen JR, Stevens MH, White JS (2009) Generalized linear mixed models: a practical guide for ecology and evolution. Trends in Ecology Evolution 24:127135. http://doi.org/10.1016/j.tree.2008.10.008

- Braidek J, Pennock D, Yates T (2008) Soil Sampling Designs. In Carter MR and Gregorich EG (eds.), Soil Sampling and Methods of Analysis, Second Edition. CRC Press. doi:10.1201/9781420005271.ch1

- 1201/9781420005271\$4ch1

- Bridgham SD, Megonigal JP, Keller JK, Bliss NB, Trettin C (2006) The carbon balance of North American wetlands. Wetlands 26:889-916. https://doi.org/10.1672/0277-

5212(2006)26[889:TCBONA]2.0.C0;2

- Calderón F, Haddix M, Conant R, Magrini-Bair K, Paul E (2013) Diffuse-Reflectance Fourier-Transform Mid-Infrared Spectroscopy as a Method of Characterizing Changes in Soil Organic Matter. Soil Sci Soc Am J 77:1591. http://doi.org/10.2136/sssaj2013.04.0131

- Calderón FJ, Mikha MM, Vigil MF, Nielsen DC, Benjamin JG, Reeves JB (2011) Diffuse-Reflectance Midinfrared Spectral Properties of Soils under Alternative Crop Rotations in a Semi-arid Climate. Commun Soil Sci Plant Anal 42:2143-2159. http://doi.org/10.1080/00103624.2011.596243

- Cambardella CA, Elliott ET (1992) Particulate soil organic-matter changes across a grassland cultivation sequence. Soil Sci Soc Am J 56:777-783.

http://doi.org/10.2136/sssaj1992.03615995005600030017x 
- Chantigny MH, Angers DA, Kaiser K, Kalbitz K (2008) Extraction and Characterization of Dissolved Organic Matter. In Carter MR and Gregorich EG (eds.), Soil Sampling and Methods of Analysis, Second Edition. CRC Press. http://doi.org/10.1201/9781420005271.ch48

- Ćirić V, Belić M, Nešić L, Šeremešić S, Pejić B, Bezdan A, Manojlović M (2016) The sensitivity of water extractable soil organic carbon fractions to land use in three soil types. Arch Agron Soil Sci 62:16541664. http://doi.org/10.1080/03650340.2016.1165345

- De Nobili M, Contin M, Chen Y (2009) Carbon sequestration in soil. In: Senesi N, Xing B, Huang PM (eds) Biophysico-chemical Processes Involving Natural Nonliving Organic Matter in Environmental Systems. John Wiley \& Sons, Inc, pp 183-217. https://doi.org/10.1002/9780470494950.ch5

- De Stefano A, Jacobson MG (2017) Soil carbon sequestration in agroforestry systems: a metaanalysis. Agrofor Syst. http://doi.org/10.1007/s10457-017-0147-9

- Deng J, Zhu W, Zhou Y, Yin Y (2019) Soil Organic Carbon Chemical Functional Groups under Different Revegetation Types Are Coupled with Changes in the Microbial Community Composition and the Functional Genes. Forests 10:240. http://doi.org/10.3390/f10030240

- Dhillon GS, Gillespie A, Peak D, Van Rees KCJ (2017) Spectroscopic investigation of soil organic matter composition for shelterbelt agroforestry systems. Geoderma 298:1-13. http://doi.org/10.1016/j.geoderma.2017.03.016

- Dimitriou I, Mola-Yudego B, Aronsson P, Eriksson J (2012) Changes in Organic Carbon and Trace Elements in the Soil of Willow Short-Rotation Coppice Plantations. BioEnergy Research 5:563-572. http://doi.org/10.1007/s12155-012-9215-1

- Ellert BH, Bettany JR (1995) Calculation of organic matter and nutrients stored in soils under contrasting management regimes. Can J Soil Sci 75:529-538. http://doi.org/10.4141/cjss95-075

- Ens J, Farrell R, Bélanger N (2013) Early Effects of Afforestation with Willow (Salix purpurea, "Hotel") on Soil Carbon and Nutrient Availability. Forests 4:137-154. https://doi.org/10.3390/f4010137

- Environment Canada (2020) Canadian climate normals 1981-2010. Available via Weather Office Canada. https://climate.weather.gc.ca/climate_normals/results_1981_2010_e.html? stnID=2925\&dispBack=0\&month1=0\&month2=12. Accessed on February 27, 2020

- Euliss NH Jr, Gleason RA, Olness A, McDougal RL, Murkin HR, Robarts RD, Bourbonniere RA, Warner BG (2006) North American prairie wetlands are important non-forested land-based carbon storage sites. Science of The Total Environment 361:179-188. https://doi.org/10.1016/j.scitotenv.2005.06.007

- Feng X, Simpson MJ (2007) The distribution and degradation of biomarkers in Alberta grassland soil profiles. Org Geochem 38:1558-1570. http://doi.org/10.1016/j.orggeochem.2007.05.001

- Ghani A, Dexter M, Perrott KW (2003) Hot-water extractable carbon in soils: a sensitive measurement for determining impacts of fertilisation, grazing and cultivation. Soil Biol Biochem 35:1231-1243. https://doi.org/10.1016/s0038-0717(03)00186-x

- Gillespie A, Gregorich E, Helgason B, Peak D (2015) Soil Instrumental Methods. p. 1-27. In Meyers RA (ed.), Encyclopedia of Analytical Chemistry. https://doi.org/10.1002/9780470027318.a0867m.pub2 
- Gleason RA, Euliss NH Jr, Tangen BA, Laubhan MK, Browne BA (2011) USDA conservation program and practice effects on wetland ecosystem services in the Prairie Pothole Region. Ecol Appl 21:S65-S81. https://doi.org/10.1890/09-0216.1

- Golchin A, Clarke P, Oades J, Skjemstad J (1995) The effects of cultivation on the composition of organic-matter and structural stability of soils. Soil Research 33:975-993. https://doi.org/10.1071/SR9950975

- Golchin A, Oades JM, Skjemstad JO, Clarke P (1994) Study of free and occluded particulate organic matter in soils by solid state 13C CP/MAS NMR spectroscopy and scanning electron microscopy. Soil Research 32:285-309. https://doi.org/10.1071/SR9940285

- Gregorich EG, Beare MH (2008) Physically Uncomplexed Organic Matter. In Carter MR and Gregorich EG (eds.), Soil Sampling and Methods of Analysis, Second Edition. CRC Press. http://doi.org/10.1201/9781420005271.ch47

- Gregorich EG, Beare MH, McKim UF, Skjemstad JO (2006) Chemical and Biological Characteristics of Physically Uncomplexed Organic Matter. Soil Sci Soc Am J, 70. http://doi.org/10.2136/sssaj2005.0116

- Gregorich EG, Monreal CM, Carter MR, Angers DA, Ellert BH (1994) Towards a minimum data set to assess soil organic matter quality in agricultural soils. Can J Soil Sci 74:367-385. https://doi.org/10.4141/cjss94-051

- Gregorich EG, Monreal CM, Schnitzer M, Schulten HR (1996) Transformation of plant residues into soil organic matter: chemical characterization of plant tissue, isolated soil fractions, and whole soils. Soil Sci 161:680-693

- Grigal DF, Berguson WE (1998) Soil carbon changes associated with short-rotation systems. Biomass Bioenerg 14:371-377. https://doi.org/10.1016/S0961-9534(97)10073-3

- Guo LB, Gifford RM (2002) Soil carbon stocks and land use change: a meta analysis Global Change Biology, 8:345-360. https://doi.org/10.1046/j.1354-1013.2002.00486.x

- Guo LBB, Wang MB, Gifford RM (2007) The change of soil carbon stocks and fine root dynamics after land use change from a native pasture to a pine plantation. Plant Soil 299:251-262. http://doi.org/10.1007/s11104-007-9381-7

- Guo X, Meng M, Zhang J, Chen HY (2016) Vegetation change impacts on soil organic carbon chemical composition in subtropical forests. Sci Rep 6:29607. http://doi.org/10.1038/srep29607

- Han L, Sun K, Jin J, Xing B (2016) Some concepts of soil organic carbon characteristics and mineral interaction from a review of literature. Soil Biol Biochem 94:107-121.

http://doi.org/10.1016/j.soilbio.2015.11.023

- Hao X, Ball BC, Culley JLB, Cater MR, Parkin GW (2008) Soil Density and Porosity. In Carter MR and Gregorich EG (eds.), Soil Sampling and Methods of Analysis, Second Edition. CRC Press. http://doi.org/10.1201/9781420005271.ch57

- Harris ZM, Alberti G, Viger M, Jenkins JR, Rowe R, McNamara NP, Taylor G (2017) Land-use change to bioenergy: grassland to short rotation coppice willow has an improved carbon balance. GCB Bioenergy 9:469-484. http://doi.org/10.1111/gcbb.12347 
- Harris ZM, Spake R, Taylor G (2015) Land use change to bioenergy: A meta-analysis of soil carbon and GHG emissions. Biomass Bioenerg 82:27-39. http://doi.org/10.1016/j.biombioe.2015.05.008

- Hättenschwiler S, Vitousek PM (2000) The role of polyphenols in terrestrial

- ecosystem nutrient cycling. Trends in Ecology and Evolution, 15:238-243. https://doi.org/10.1016/S0169-5347(00)01861-9

- Helfrich M, Ludwig B, Buurman P, Flessa H (2006) Effect of land use on the composition of soil organic matter in density and aggregate fractions as revealed by solid-state 13C NMR spectroscopy. Geoderma 136:331-341. http://doi.org/10.1016/j.geoderma.2006.03.048

- Janzen HH (2004) Carbon cycling in earth systems-a soil science perspective. Agriculture. Ecosystems Environment 104:399-417. https://doi.org/10.1016/j.agee.2004.01.040

- Janzen HH, Campbell CA, Izaurralde RC, Ellert BH, Juma N, McGill WB, Zentner RP (1998) Management effects on soil C storage on the Canadian prairies. Soil Tillage Research 47:181-195. http://dx.doi.org/10.1016/S0167-1987(98)00105-6

- Jobbágy EG, Jackson RB (2000) The vertical distribution of soil organic carbon and its relation to climate and vegetation. Ecol Appl 10:423-436. https://doi.org/10.1890/1051-

0761(2000)010[0423:TVDOSO]2.0.C0;2

- Kayranli B, Scholz M, Mustafa A, Hedmark Å (2009) Carbon Storage and Fluxes within Freshwater Wetlands: a Critical Review. Wetlands 30:111-124. http://doi.org/10.1007/s13157-009-0003-4

- Krzywinski M, Altman N, Blainey P (2014) Nested designs. Nat Methods 11:977-978. http://doi.org/10.1038/nmeth.3137

- Kuzovkina YA, Quigley MF (2005) Willows beyond wetlands: uses of Salix L. species for environmental projects. Water Air Soil Pollution 162:183-204. https://doi.org/10.1007/s11270-005-6272-5

- Lafleur B, Labrecque M, Arnold AA, Belanger N (2015) Organic Carbon Accumulation in Topsoil Following Afforestation with Willow: Emphasis on Leaf Litter Decomposition and Soil Organic Matter Quality. Forests 6:769-793. https://doi.org/10.3390/f6030769

- Laganière J, Angers DA, Paré D (2010) Carbon accumulation in agricultural soils after afforestation: a meta-analysis. Glob Change Biol 16:439-453. http://doi.org/10.1111/j.1365-2486.2009.01930.x

- Lal R (2004) Soil Carbon Sequestration Impacts on Global Climate Change and Food Security. science, 304:1623-1626. http://doi.org/10.1126/science.1097396

- Lal R (2006) Carbon Management in Agricultural Soils. Mitigation and Adaptation Strategies for Global Change, 12:303-322. http://doi.org/10.1007/s11027-006-9036-7

- Lemus R, Lal R (2005) Bioenergy Crops and Carbon Sequestration. Crit Rev Plant Sci 24:1-21. http://doi.org/10.1080/07352680590910393

- Liu T, Huffman T, Kulshreshtha S, McConkey B, Du Y, Green M, Liu J, Shang J, Geng X (2017a) Bioenergy production on marginal land in Canada: Potential, economic feasibility, and greenhouse gas emissions impacts. Appl Energy 205:477-485 
- Liu X, Li L, Qi Z, Han J, Zhu Y (2017b) Land-use impacts on profile distribution of labile and recalcitrant carbon in the lli River Valley, northwest China. Science of The Total Environment 586:10381045. https://doi.org/10.1016/j.scitotenv.2017.02.087

- Lockwell J, Guidi W, Labrecque M (2012) Soil carbon sequestration potential of willows in shortrotation coppice established on abandoned farm lands. Plant Soil 360:299-318. https://doi.org/10.1007/s11104-012-1251-2

- Lucas ST, Weil RR (2012) Can a Labile Carbon Test be Used to Predict Crop Responses to Improve Soil Organic Matter Management? Agron J 104:1160. http://doi.org/10.2134/agronj2011.0415

- Mirsky SB, Lanyon LE, Needelman BA (2008) Evaluating soil management using particulate and chemically labile soil organic matter fractions. Soil Sci Soc Am J 72:180-185. http://doi.org/10.2136/sssaj2005.0279

- Mitsch WJ, Gosselink JG (2015) Wetlands Fifth Edition edition. John Wiley \& Sons, Inc., Hoboken, New Jersey, USA

- Nair RPK, Nair VD, Mohan Kumar B, Showalter JM (2010) Carbon Sequestration in Agroforestry Systems. p. 237-307. In Donald LS (ed.), Advances in Agronomy. Academic Press. http://dx.doi.org/10.1016/S0065-2113(10)08005-3

- Oelbermann M, Paul Voroney R, Gordon AM (2004) Carbon sequestration in tropical and temperate agroforestry systems: a review with examples from Costa Rica and southern Canada. Agr Ecosyst Environ 104:359-377. https://doi.org/10.1016/j.agee.2004.04.001

- Ondrasek G, Bakic Begic H, Zovko M, Filipovic L, Merino-Gergichevich C, Savic R, Rengel Z (2019) Biogeochemistry of soil organic matter in agroecosystems \& environmental implications. Science of The Total Environment 658:1559-1573. https://doi.org/10.1016/j.scitotenv.2018.12.243

- Pacaldo RS, Volk TA, Briggs RD (2013) No significant differences in soil organic carbon contents along a chronosequence of shrub willow biomass crop fields. Biomass Bioenerg 58:136-142. https://doi.org/10.1016/j.biombioe.2013.10.018

- Paul EA (2016) The nature and dynamics of soil organic matter: Plant inputs, microbial transformations, and organic matter stabilization. Soil Biol Biochem 98:109-126. https://doi.org/10.1016/j.soilbio.2016.04.001

- Paul S, Veldkamp E, Flessa H (2008) Soil organic carbon in density fractions of tropical soils under forest - pasture - secondary forest land use changes. Eur J Soil Sci 59:359-371.

https://doi.org/10.1111/j.1365-2389.2007.01010.x

- Paustian K, Lehmann J, Ogle S, Reay D, Robertson GP, Smith P (2016) Climate-smart soils. Nature 532:49-57. https://doi.org/10.1038/nature17174

- Pennock DJ, Zebarth BJ, Jong ED (1987) Landform Classification and Soil Distribution in Hummocky Terrain. Saskatchewan Canada Geoderma 40:297-315

- Puget P, Lal R (2005) Soil organic carbon and nitrogen in a Mollisol in central Ohio as affected by tillage and land use. Soil Tillage Research 80:201-213. https://doi.org/10.1016/j.still.2004.03.018 
- Purakayastha TJ, Chhonkar PK, Bhadraray S, Patra AK, Verma V, Khan MA (2007) Long-term effects of different land use and soil management on various organic carbon fractions in an Inceptisol of subtropical India. Aust J Soil Res 45:33-40. http://doi.org/10.1071/sr06077

- Qin Z, Dunn JB, Kwon H, Mueller S, Wander MM (2016) Soil carbon sequestration and land use change associated with biofuel production: empirical evidence. GCB Bioenergy 8:66-80. https://doi.org/10.1111/gcbb.12237

- R Core Team (2018) R: A Language and Environment for Statistical Computing. R Foundation for Statistical Computing, Vienna, Austria https://www.r-project.org/

- Rahman MM, Rahman MM (2012) Quantitative Chemical Defense Traits, Litter Decomposition and Forest Ecosystem Functioning. In Blanco JA and Lo Y-H (eds.), Forest Ecosystems - More than Just Trees. IntechOpen. http://doi.org/10.5772/39003

- Ramesh T, Bolan NS, Kirkham MB, Wijesekara H, Kanchikerimath M, Srinivasa Rao C, Sandeep S, Rinklebe J, Ok YS, Choudhury BU, Wang H, Tang C, Wang X, Song Z, Freeman li OW (2019) Soil organic carbon dynamics: Impact of land use changes and management practices: A review. p. 1-107. In Sparks DL (ed.), Advances in Agronomy. Elsevier Inc. https://doi.org/10.1016/bs.agron.2019.02.001

- Rumpel C, Kögel-Knabner I (2010) Deep soil organic matter-a key but poorly understood component of terrestrial C cycle. Plant Soil 338:143-158. http://doi.org/10.1007/s11104-010-0391-5

- Sainepo BM, Gachene CK, Karuma A (2018) Assessment of soil organic carbon fractions and carbon management index under different land use types in Olesharo Catchment, Narok County, Kenya. Carbon Balance Management 13:4. http://doi.org/10.1186/s13021-018-0091-7

- Saskatchewan Soil Survey Staff (1986) Soil Survey Reports for Saskatchewan: The Soils of Indian Head, Rural Municipalty no 156 Saskatchewan. Saskatchewan Institute of Pedology Publication S202, Saskatoon, Saskatchewan http://sis.agr.gc.ca/cansis/publications/surveys/sk/sks202/index.html

- Schimel JP, Schaeffer SM (2012) Microbial control over carbon cycling in soil. Front Microbiol 3:348. https://doi.org/10.3389/fmicb.2012.00348

- Schmidt MW, Torn MS, Abiven S, Dittmar T, Guggenberger G, Janssens IA, Kleber M, Kogel-Knabner I, Lehmann J, Manning DA, Nannipieri P, Rasse DP, Weiner S, Trumbore SE (2011) Persistence of soil organic matter as an ecosystem property. Nature 478:49-56. https://doi.org/10.1038/nature10386

- Schoeneberger MM (2008) Agroforestry: working trees for sequestering carbon on agricultural lands. Agrofor Syst 75:27-37. http://doi.org/10.1007/s10457-008-9123-8

- Schofield JA, Hagerman AE, Harold A (1998) Loss of Tannins and Other Phenolics from Willow Leaf Litter. J Chem Ecol 24:1409-1421. https://doi.org/10.1023/A:1021287018787

- Six J, Callewaert P, Lenders S, De Gryze S, Morris SJ, Gregorich EG, Paul EA, Paustian K (2002a) Measuring and understanding carbon storage in afforested soils by physical fractionation. Soil Sci Soc Am J 66:1981-1987. https://doi.org/10.2136/sssaj2002.1981

- Six J, Conant RT, Paul EA, Paustian K (2002b) Stabilization mechanisms of soil organic matter: implications for C-saturation of soils. Plant Soil 241:155-176.

https://doi.org/10.1023/A:1016125726789

Page 24/33 
- Skjemstad JO, Baldock JA (2008) Total and Organic Carbon. In Carter MR and Gregorich EG (eds.), Soil Sampling and Methods of Analysis, Second Edition. CRC Press.

http://doi.org/10.1201/9781420005271.ch21

- Solomon D, Lehmann J, Kinyangi J, Liang B, Scha“fer T (2005) Carbon K-Edge NEXAFS and FTIR-ATR Spectroscopic Investigation of Organic Carbon Speciation in Soils. Soil Sci Soc Am J. http://doi.org/10.2136/sssaj2005.0107dup

- Stauffer M, Leyval C, Brun JJ, Leportier P, Berthelin J (2014) Effect of willow short rotation coppice on soil properties after three years of growth as compared to forest, grassland and arable land uses. Plant Soil 377:423-438. http://doi.org/10.1007/s11104-013-1986-4

- Stockmann U, Adams MA, Crawford JW, Field DJ, Henakaarchchi N, Jenkins M, Minasny B, McBratney AB, Courcelles VdRd, Singh K, Wheeler I, Abbott L, Angers DA, Baldock J, Bird M, Brookes PC, Chenu C, Jastrow JD, Lal R, Lehmann J, O'Donnell AG, Parton WJ, Whitehead D, Zimmermann M (2013) The knowns, known unknowns and unknowns of sequestration of soil organic carbon. Agr Ecosyst Environ 164:80-99. http://doi.org/10.1016/j.agee.2012.10.001

- Vancampenhout K, De Vos B, Wouters K, Swennen R, Buurman P, Deckers J (2012) Organic matter of subsoil horizons under broadleaved forest: Highly processed or labile and plant-derived? Soil Biol Biochem 50:40-46. http://doi.org/10.1016/j.soilbio.2012.03.005

- Vepraskas MJ, Craft CB (2016) Wetland Soils: Genesis, Hydrology, Landscapes, and Classification Second Edition edition. CRC Press, Taylor \& Francis Group, Boca Raton, FL, USA

- Winter TC (1989) Hydrologic studies of the wetlands in the northern prairie. p. 400. In: Van der Valk A (ed) Northern Prairie Wetlands. lowa State University Press Ames, lowa.

https://pubs.er.usgs.gov/publication/70196002

- Young R, Wilson BR, McLeod M, Alston C (2005) Carbon storage in the soils and vegetation of contrasting land uses in northern New South Wales, Australia. Aust J Soil Res 43:21-31. http://doi.org/10.1071/sr04032

- Zhang JB, Song CC, Yang WY (2006) Land use effects on the distribution of labile organic carbon fractions through soil profiles. Soil Sci Soc Am J 70:660-667. http://doi.org/10.2136/sssaj2005.0007

\section{Figures}




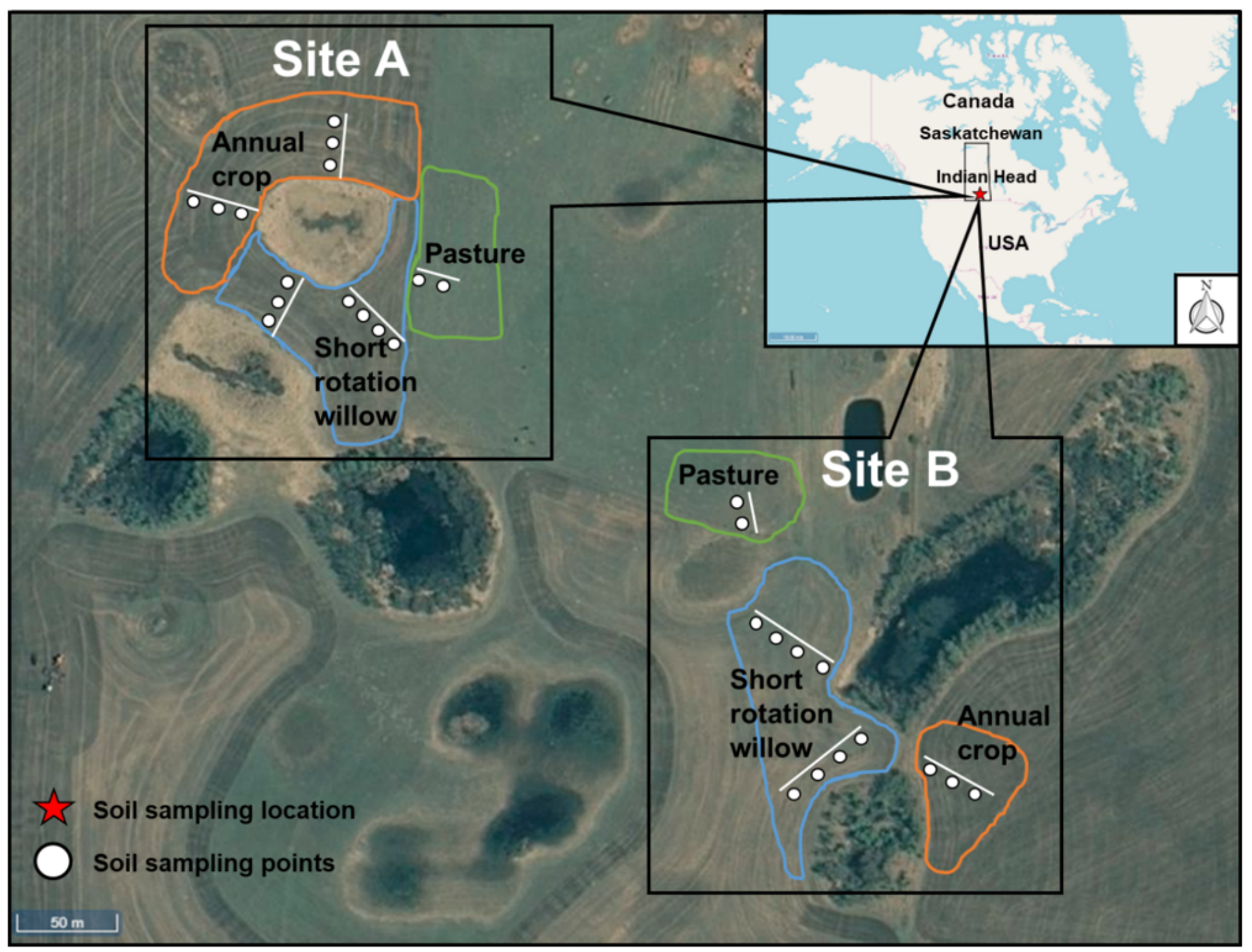

\section{Figure 1}

Map of the field study location, site areas, and soil sampling points along transects displayed with red dot, black lines, and white dots, respectively. The map is extracted from Saskatchewan Geospatial Imagery Collaborative (2020). 


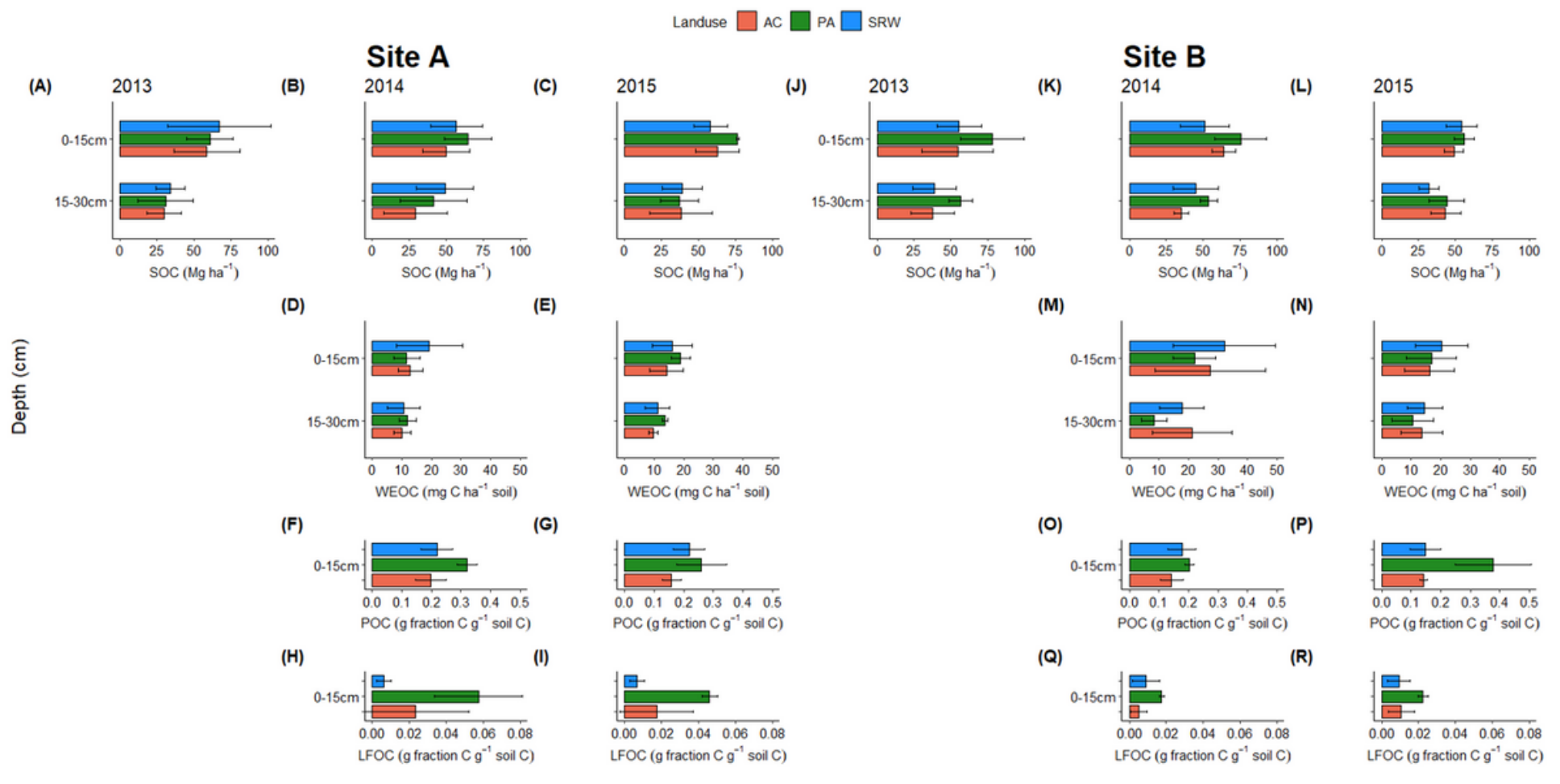

Figure 2

Distribution (mean \pm standard deviation) of soil organic carbon (SOC) and different labile carbon fractions measured under annual crop (AC), pasture (PA), and short rotation willow (SRW) at different soil depths (i.e., 01-15 cm and 15-30 cm) in 2013, 2014, and 2015. Panels A, B, and C from site A, while J, K, and $L$ from site $B$ showing SOC at 0-15 cm and 15-30 cm depths in 2013, 2014, and 2015, respectively. Panels $D$ and $E$ from site $A$, while $M$ and $N$ from site $B$ showing water extractable organic carbon (WEOC) at 0-15 cm and 15-30 cm depths in 2014 and 2015, respectively. Panels $F$ and $G$ from site A, while $O$ and $\mathrm{P}$ from site B showing particulate organic carbon (POC) in 2014 and 2015, respectively. Panels $\mathrm{H}$ and I from site A, while $Q$ and R from site B showing light fraction organic carbon (LFOC) in 2014 and 2015, respectively. 
Site A

(A)

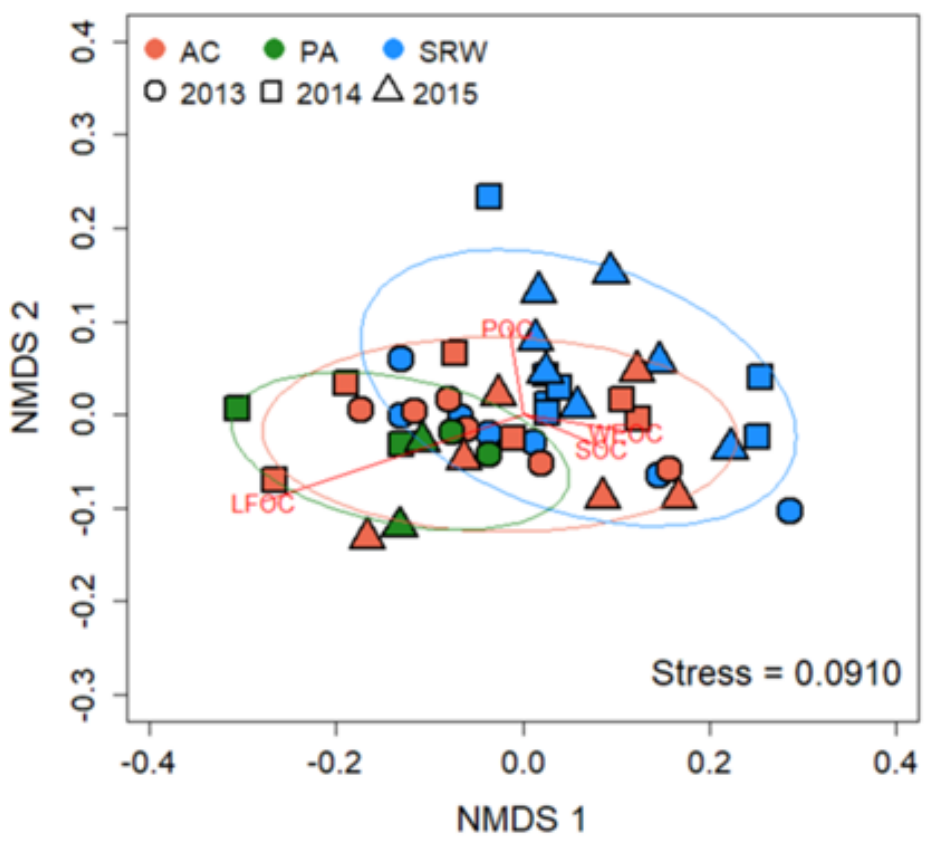

(C)

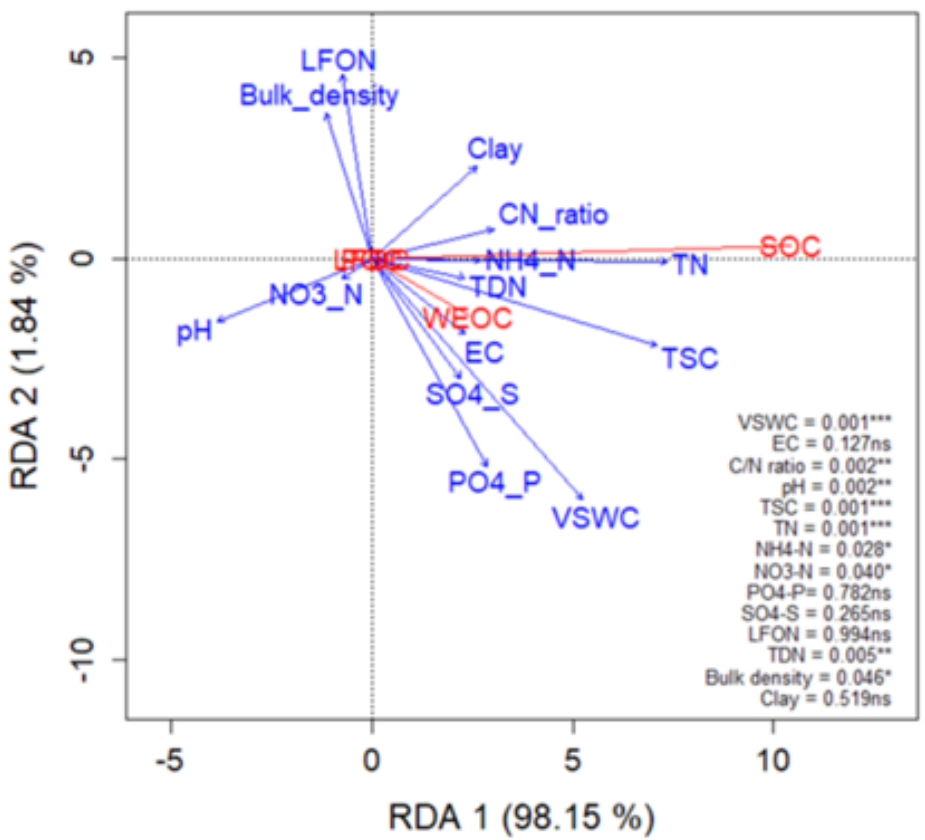

(B)

Site B

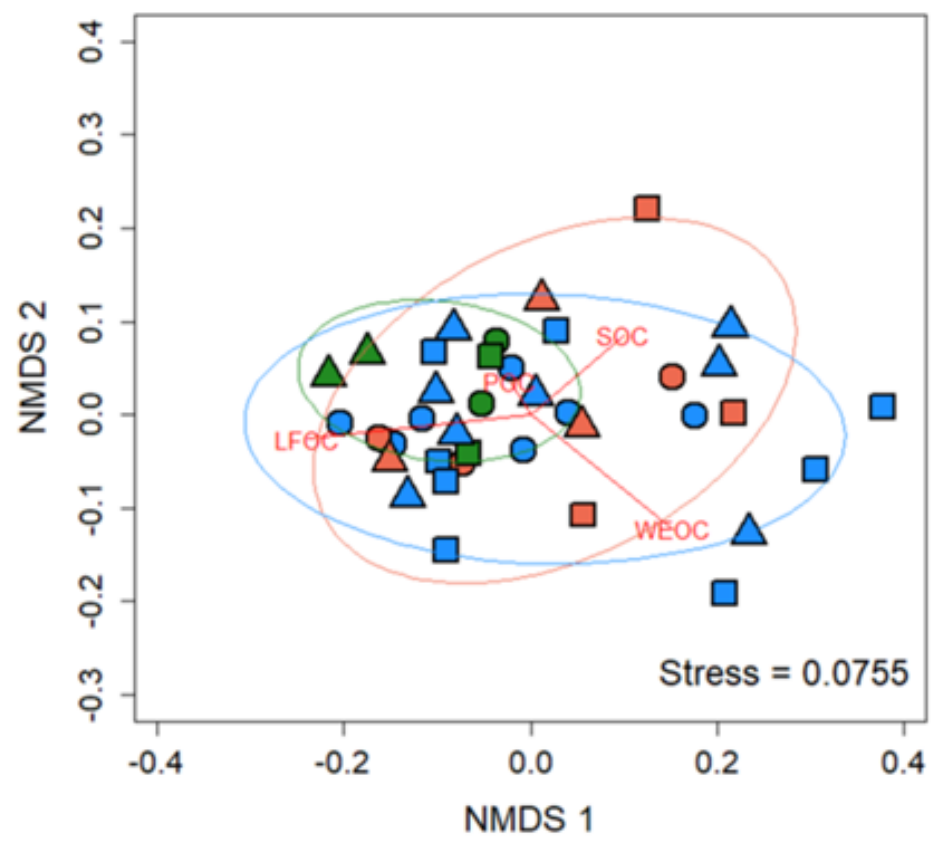

(D)

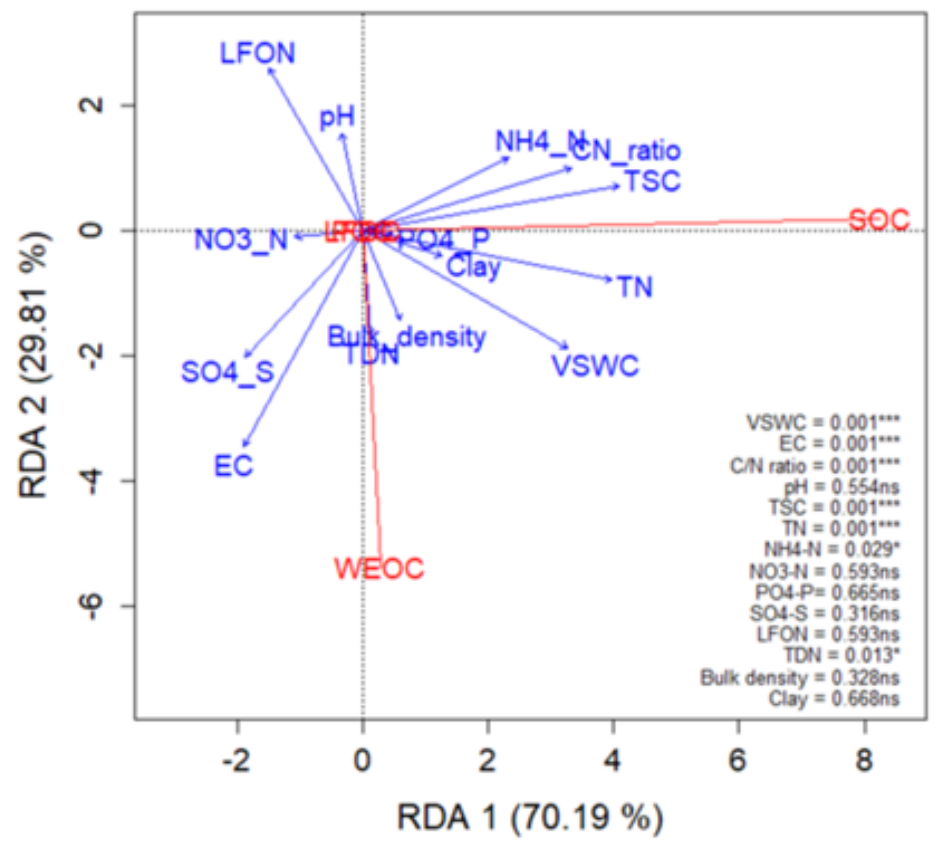

\section{Figure 3}

Non-metric multidimensional scaling (NMDS) ordination of soil organic carbon (SOC) and labile carbon fractions (i.e., water extractable organic carbon $=$ WEOC, particulate organic carbon $=$ POC, and light fraction organic carbon $=$ LFOC), and redundancy analysis (RDA) illustrating the effects of measured soil physical and chemical characteristics from site $A$ ( $A$ and $C$ ), and site $B$ ( $B$ and $D$ ) under different land-use practices (i.e., annual crop $=$ AC, pasture $=$ PA, and short rotation willow $=$ SRW) in 2013, 2014, and 2015. 
Blue vectors $(r>x)$ from RDA plots (panels $C$ and $D$ ) indicate linear correlations between the ordination and soil physical and chemical properties (variables), namely $\mathrm{pH}$, clay, bulk density, electrical conductivity (EC), volumetric soil water content (VSWC), C/N ratio, NH4+-N, NO3-N, PO43--P, SO42--S, total soil carbon (TSC), total nitrogen (TN), light fraction organic nitrogen (LFON), and total dissolved nitrogen (TDN). Directions and lengths of the vectors indicate the strength of correlations between variables. The angles between vectors reflect their correlations (i.e., a vector pair with an angle of $20^{\circ}$ have strong positive correlation as $\cos (20)=0.94$, and with an angle of $90^{\circ}$ are uncorrelated as $\left.\cos (90)=0\right) . *, * *$, $* \star *$ Indicate there is a statistically significant difference at $p \leq 0.05, p \leq 0.01$ and $p \leq 0.001$, respectively; ns, is not significantly different $(p>0.05)$. 
Site A

(A)

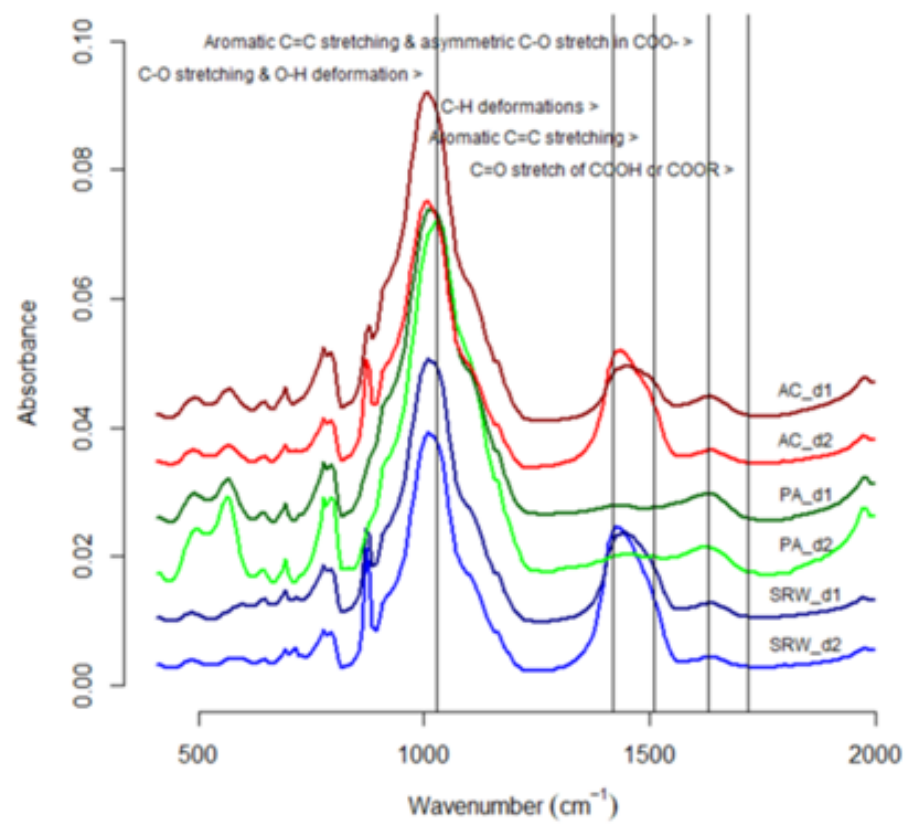

(C)

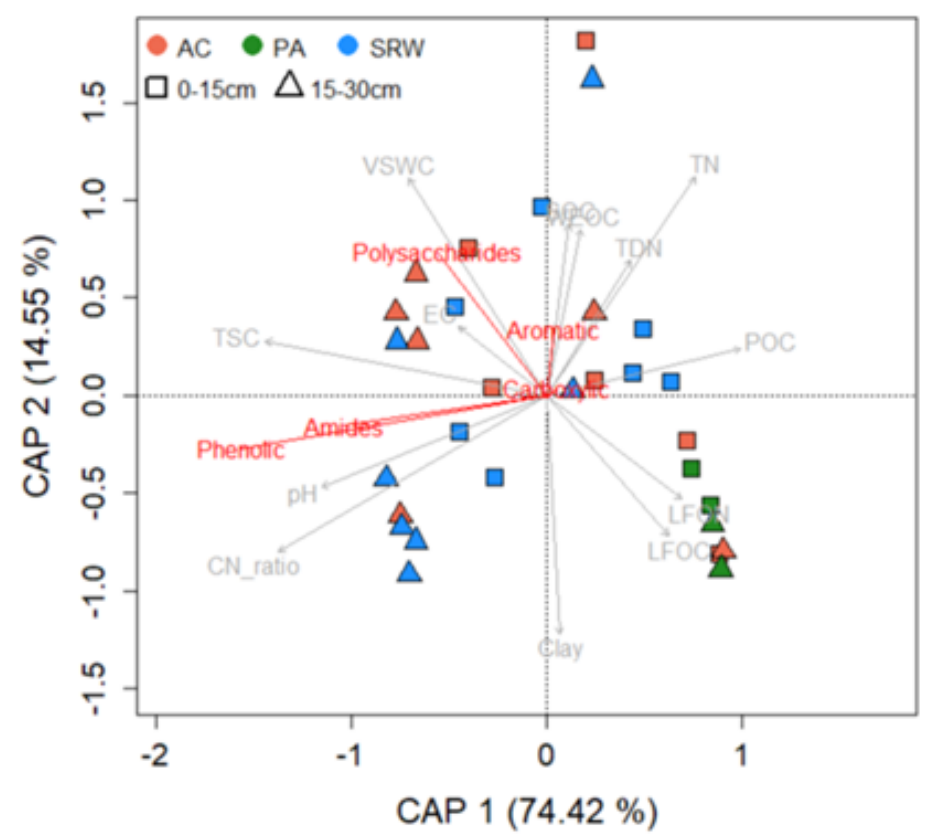

Site B

(B)

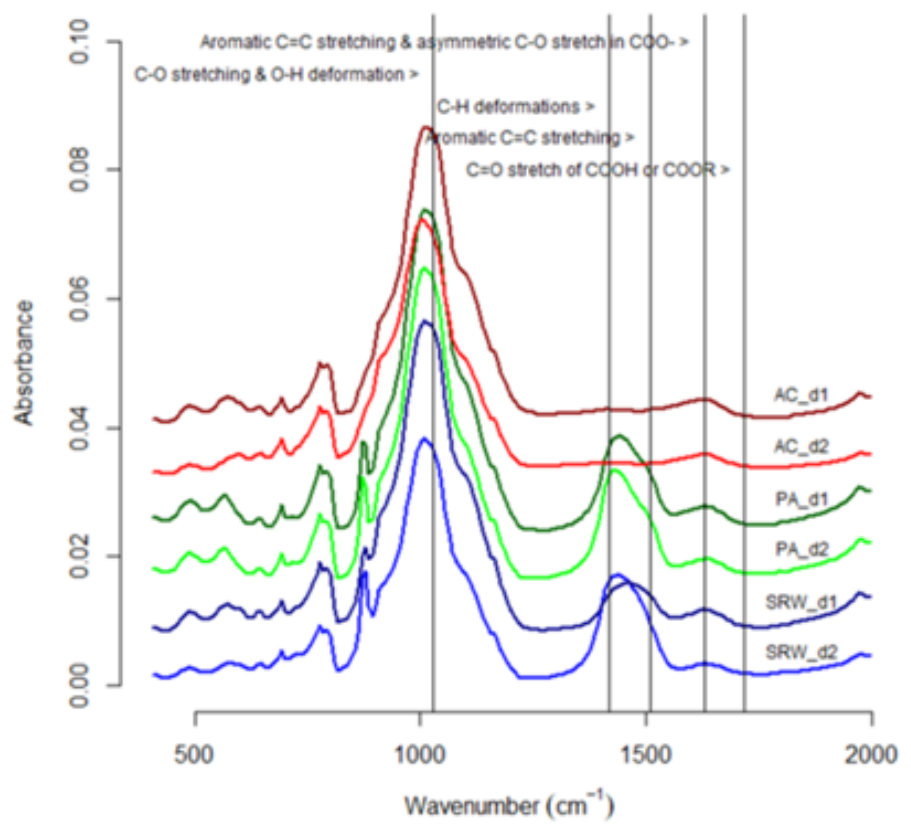

(D)

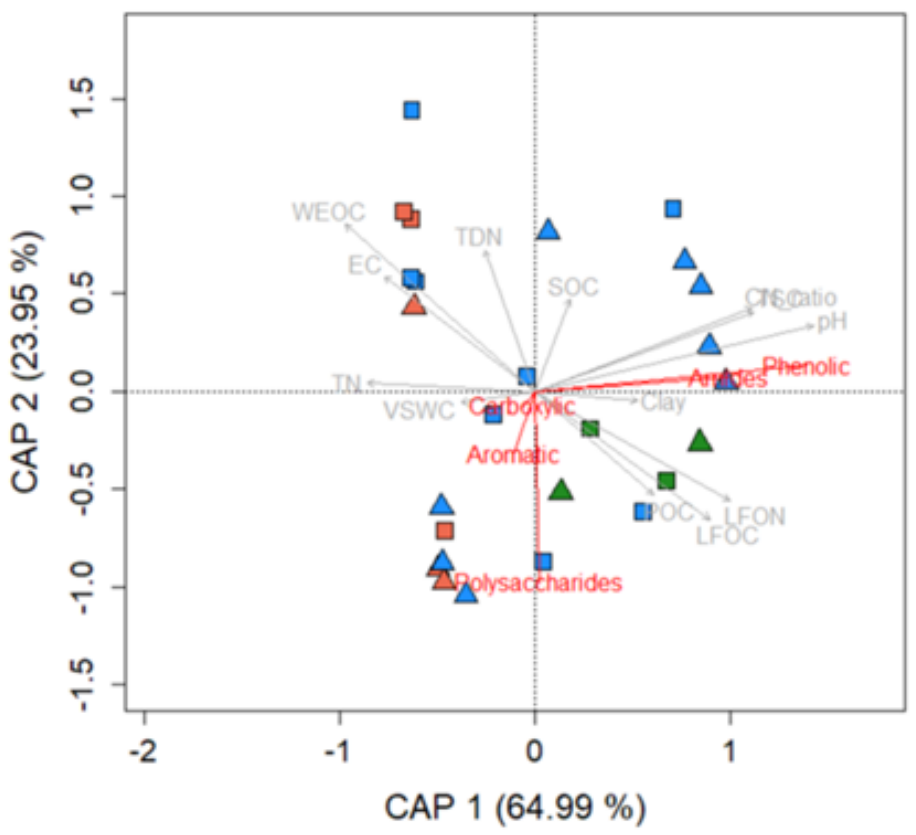

\section{Figure 4}

Fourier-transform infrared spectroscopy (FTIR) spectra (normalized and averaged), and constrained analysis of principal coordinates (CAP) of chemical functional groups [i.e., $1030=$ polysaccharides (C-0), $1420=$ phenolic $(\mathrm{C}-\mathrm{H}), 1510=$ amides $(\mathrm{N}-\mathrm{H}), 1630=$ aromatic $(\mathrm{C}=\mathrm{C})$, and $1720=$ carboxylic $(\mathrm{C}=\mathrm{O})]$ of soil organic carbon (SOC) and labile carbon fractions (i.e., water extractable organic carbon =WEOC, particulate organic carbon $=\mathrm{POC}$, and light fraction organic carbon $=$ LFOC) measured in soils under 
different land-use practices (i.e., annual crop $=A C$, pasture $=P A$, and short rotation willow $=S R W$ ) at different soil depths (i.e., $d 1=0-15 \mathrm{~cm}$ and $\mathrm{d} 2=15-30 \mathrm{~cm}$ ) from site $A(A$ and $C)$, and site $B(B$ and $D)$. Straight vertical black lines crossing different FTIR spectra on the plots (panels A and B) are spectral regions of known band absorption features related to different chemical functional groups that coincide with identified absorbance peaks. Gray vectors $(r>x)$ from CAP plots (panels $C$ and $D$ ) indicate linear correlations between the ordination and soil physical and chemical properties (variables), namely $\mathrm{pH}$, clay, bulk density, electrical conductivity (EC), volumetric soil water content (VSWC), C/N ratio, NH4+-N, NO3-N, PO43-P, SO42-S, total soil carbon (TSC), total nitrogen (TN), light fraction organic nitrogen (LFON), and total dissolved nitrogen (TDN). Directions and lengths of the vectors indicate the strength of correlations between variables. The angles between vectors reflect their correlations (i.e., a vector pair with an angle of $20^{\circ}$ have strong positive correlation as $\cos (20)=0.94$, and with an angle of $90^{\circ}$ are uncorrelated as $\cos (90)=0)$. 
Site A

(A)

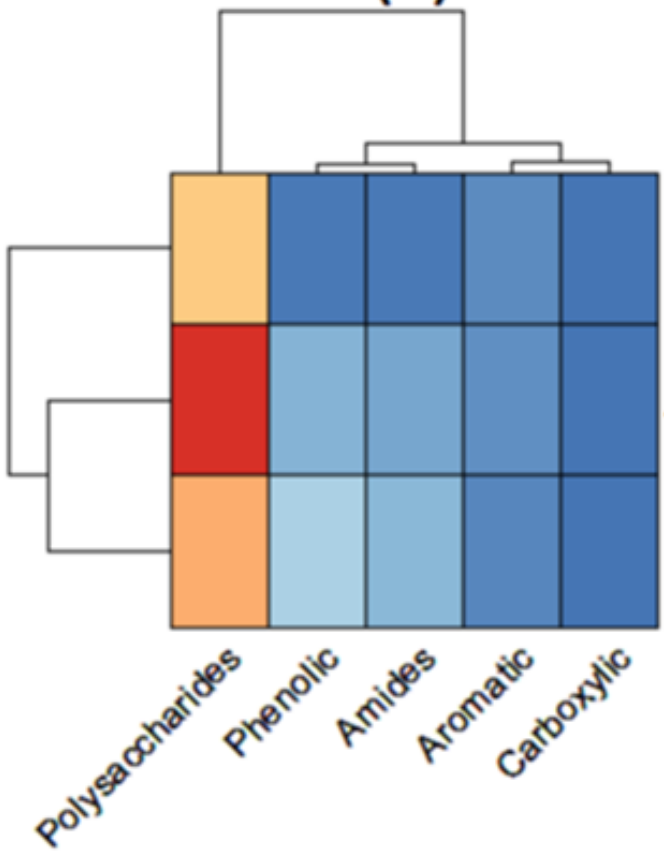

(C)

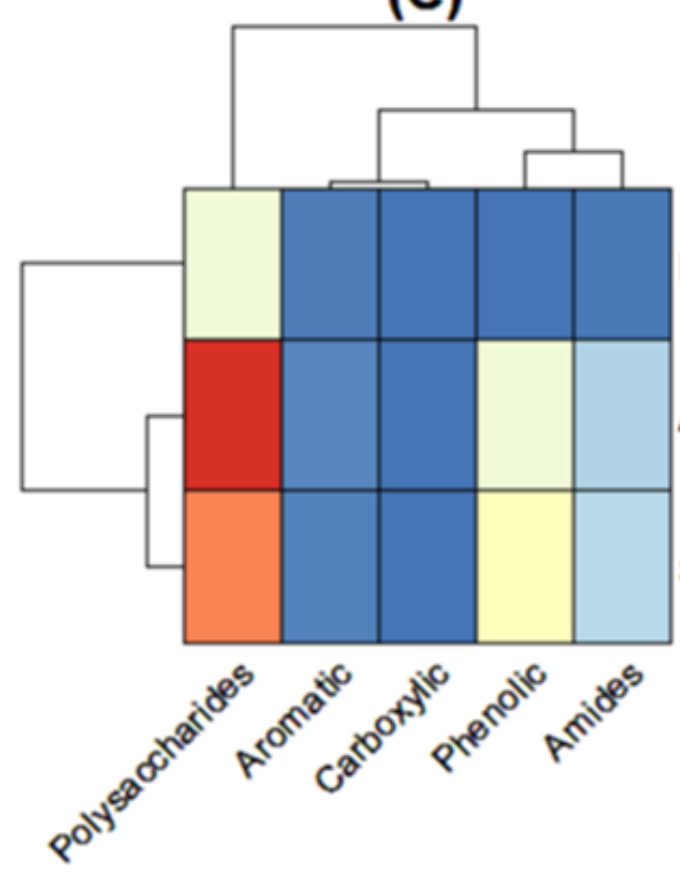

Site B

(B)

$0-15 \mathrm{~cm}$

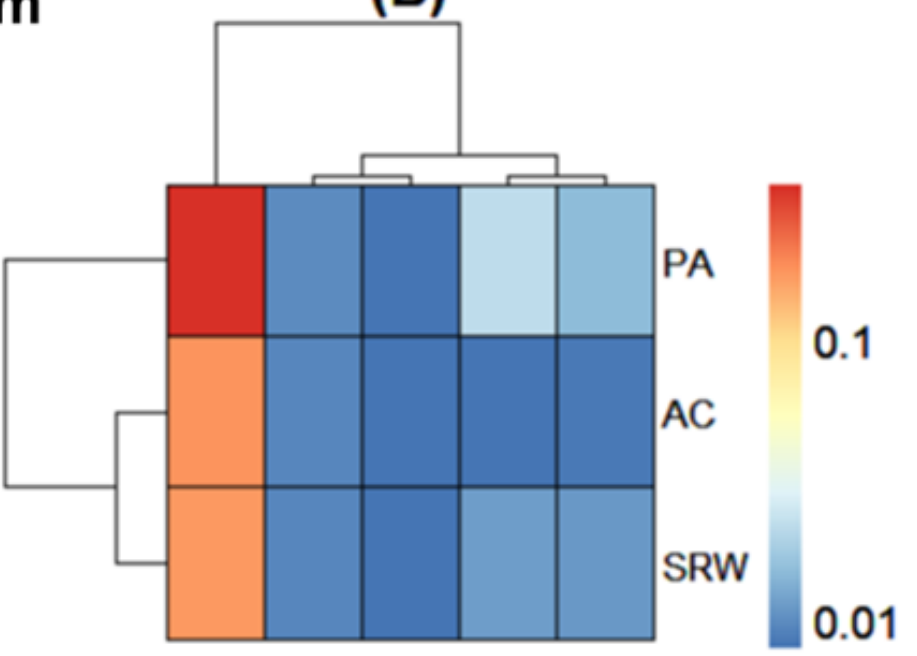

0.01

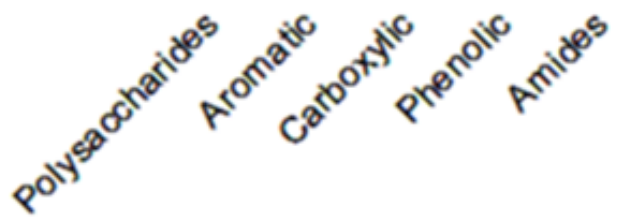

(D)

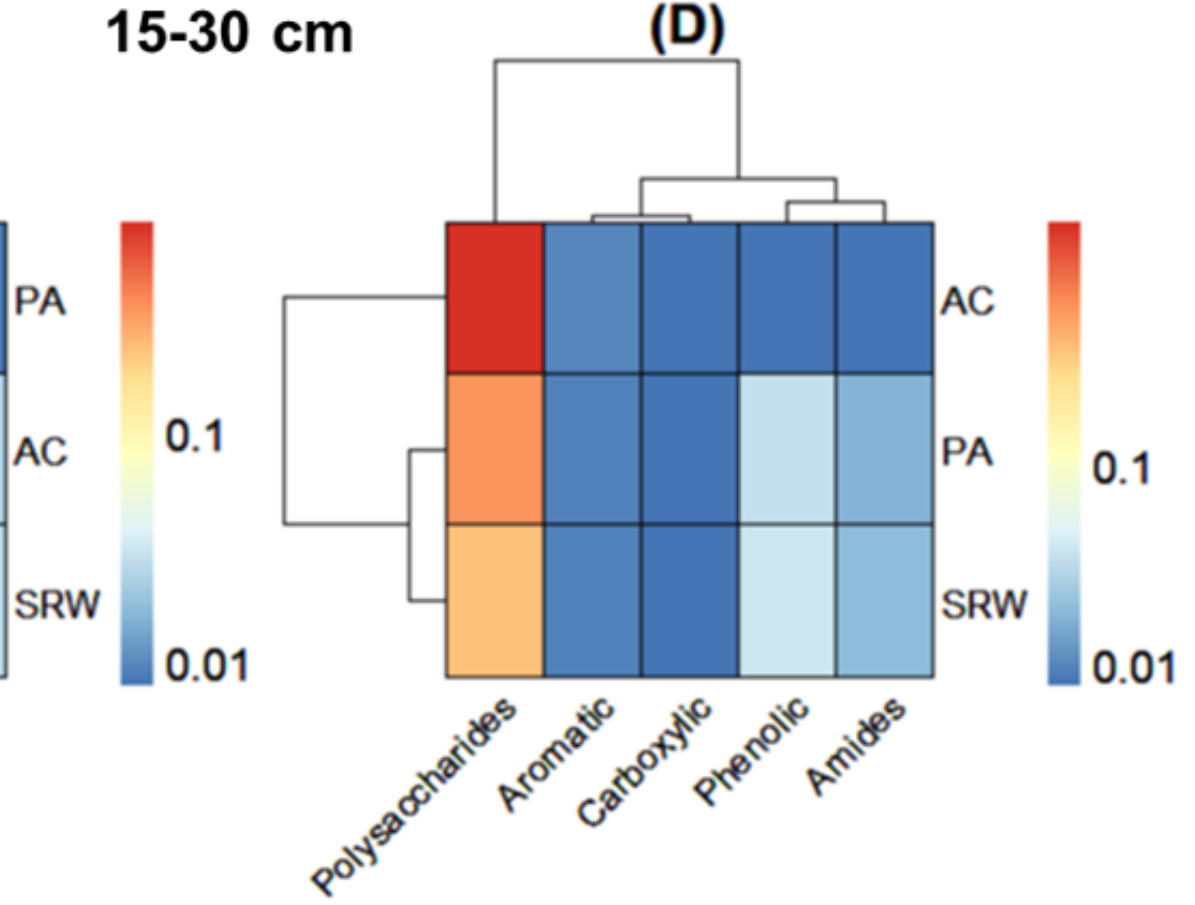

Figure 5

Heatmap with hierarchical cluster analysis (HCA) show the grouping based on different chemical functional groups (i.e., polysaccharides, phenolic, amides, aromatic, and carboxylic) of soil organic carbon and labile carbon fractions (i.e., water extractable organic carbon, particulate organic carbon, and light fraction organic carbon) and land-use practices (i.e., annual crop = AC, pasture = PA, and short 
rotation willow $=S R W)$ from site $A(A$ and $C)$, and site $B(B$ and $D)$ at different soil depths (i.e., $0-15 \mathrm{~cm}$ and $15-30 \mathrm{~cm}$ ).

\section{Supplementary Files}

This is a list of supplementary files associated with this preprint. Click to download.

- Graphicalabstractv2.tif

- Highlights.docx 